\title{
Challenges of Linking Socio-Economic Significance and Conservation Value of Forests in Drylands of Kenya: Case Study of Kirisia Forest-Samburu Pastoralists Coexistence
}

\author{
Joseph Hitimana ${ }^{1}$ et al. ${ }^{*}$ \\ ${ }^{1}$ Kabianga University College, Kabianga \\ Kenya
}

\section{Introduction}

According to IUCN, UNEP and WWF, sustainability encompasses improving the quality of human life within the carrying capacity of supporting eco-systems (Figure 1).

Rural communities around the Kirisia forest are mainly pastoralists whose livelihoods highly depend on livestock dominated by cattle. The forest is an important source of browse, grazing land and water particularly during drought. Forests as natural resources are associated with economic value, aesthetic value, legal value and ethical value. People have the moral duty to protect and conserve the resources for future generations. On the productive front, a natural resource value rests in the amount and extractability of the material available and the demand for it.

The Kirisia Forest Reserve is a critical habitat for a rich wildlife and supports the livelihoods of adjacent communities to an extent that is not exhaustively documented. Both the wildlife and people can inflict negative impacts on the ecosystem if they are not checked and controlled. At the moment, most of the human activities within the Kirisia forest, as in all the natural forests in Kenya, are not planned, controlled nor coordinated. There is lack of management plans, scanty research findings and poor documentation of indigenous knowledge which all together are fundamental prerequisite to the sustainable management and conservation of natural forests. No forest management option can be sustainable unless the interests and needs of people and other living components linked to or dependent on the ecosystem are integrated into a management plan (Odhiambo, 2005). According to Eckersley (1992), conservation should be based on three principles: (i) the development of natural

\footnotetext{
* James Legilisho Ole Kiyiapi², Pauline Wambui Kibugi3 ${ }^{3}$ Hamphrey Kisioh ${ }^{4}$, Rose Mayienda ${ }^{5}$, Fiesta Warinwa ${ }^{5}$, Philip Lenaiyasa ${ }^{5}$ and Daudi Sumba ${ }^{5}$

${ }^{2}$ Ministry of Education, Nairobi, Kenya

${ }^{3}$ Chepkoilel University College, Eldoret, Kenya

${ }^{4}$ REAPS-Consult Ltd, Nairobi, Kenya

${ }^{5}$ African Wildlife Foundation, Nairobi, Kenya
} 


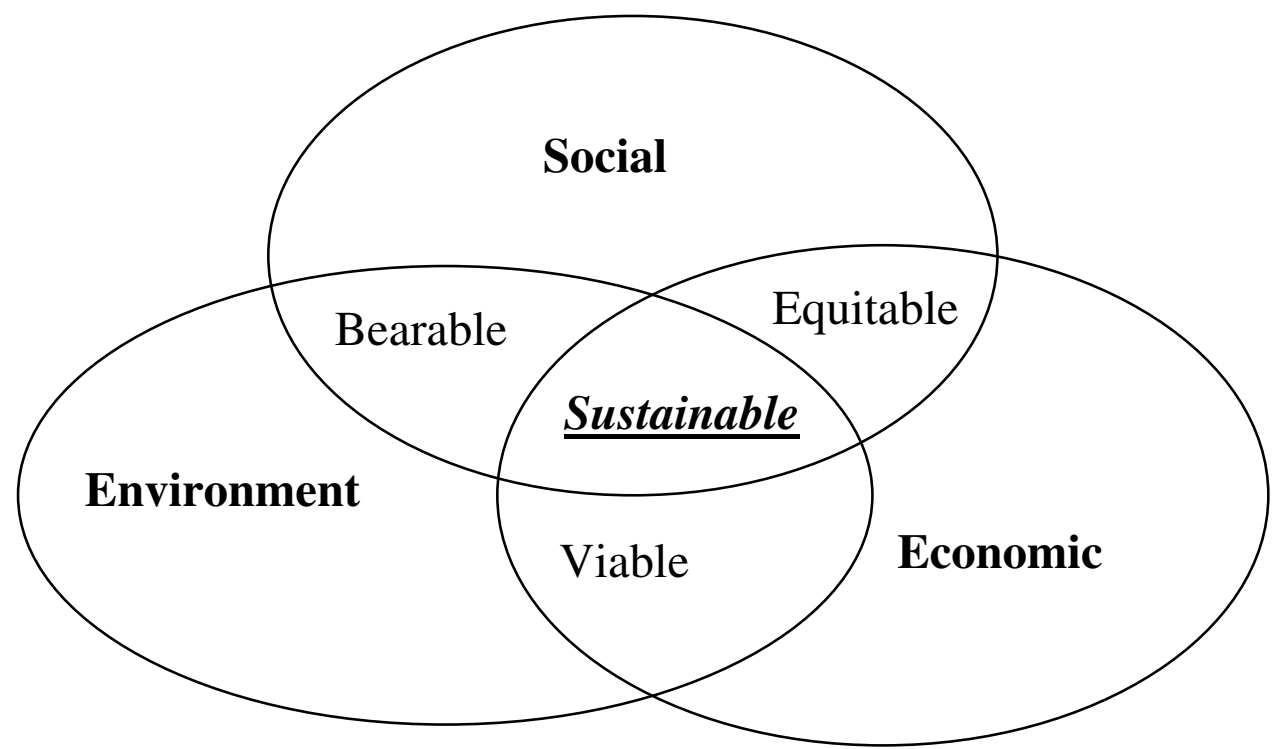

Fig. 1. Scheme of sustainable development of resources (economically viable and equitable; environmentally viable and bearable; and socially bearable and equitable).

resources under scientific management, (ii) reduction of waste and (iii) equity in access to resources based on the ideals of human welfare ecology which also emphasizes environmental quality and social issues such as recreation, spiritual and psychological needs (ecosystem management concept). The level of disturbance to the Kirisia forest ecosystem through human activities and other uses was (before this study) not known and there had been no measure of the actual socio-economic value of the Kirisia forest to its immediate users, which are local adjacent communities. Local communities must be empowered in knowledge, structures and technologies to ensure sustainable utilization of communitybased natural resources for improved livelihoods, environmental protection and sustainable development. Realizing that the capacity of the Government alone to conserve the Kirisia forest is limited, African Wildlife Foundation (AWF) initiated the process of informationgathering about the ecosystem by commissioning scientific studies in order to use findings to enlighten members of adjacent Group Ranches and motivate them to support participatory forest management initiatives and avoid over-reliance on the forest resources. AWF is known to support pastoral communities in wildlife-rich landscapes to adopt integrated land use models that are developmental and conservation-friendly. The AWF mission is to work with the people of Africa and AWF supporters to conserve the wildlife and wildlands of Africa. Improving livelihood of people in regions where AWF operates and to support wildlife conservation initiatives both within and outside protected areas are some of AWF's key objectives under its landscape conservation program branded: "the African Heartlands Program". Many studies commissioned by AWF about Kirisia forest ecosystem include forest assessment which emphasised different forest uses in blocks bordering two Group Ranches, Baawa and Lpartuk (Watai and Gachathi, 2003). In these blocks, the following tasks were undertaken: a general inventory of common plant species, identifying commonly used nontimber forest products and main threats to key species, and exploring opportunities for low- 
impact eco-tourism and other sustainable economic activities. The survey was conducted using various participatory methods including: group discussions, transect walks/drives, demonstrations, observations and excursions to selected areas. Ecologically, it was of low intensity but generated useful information. The study revealed that Kirisia forest is of considerable ecological, social and economic importance to the surrounding communities. In addition to its role as a water catchment, the forest is the source of dry season fodder, medicine for people and livestock, firewood, building poles, fruits, edible roots and tubers, vegetables, oils, dyes, fibres, honey and various items of culture among others. Most plants have clearly defined place in the life of the people either through material value, ceremonial or ritual meaning. A total of 96 plant species in 42 families were identified. These are put into various uses (Watai and Gachathi, 2003). Another study dealt with assessment of bee-keeping potential in the area (MKK, 2005). This study was carried out in six Group Ranches to establish a baseline for future monitoring of the impact of a refinery on bee keeping, income generation and forest conditions. Beekeepers' perception of the condition of the forest, their willingness to put their hives in the forest, other forest uses and expenditure patterns were also investigated. AWF also has supported the development of tourism strategy for Samburu District in 2007 which proposed tourism development initiatives in several Group Ranches including those around Kirisia forest (Ikua \& Sommerlatte, 2007). Finally, in 2005, AWF commissioned a more comprehensive and integrated study simultaneously combining both ecological and socioeconomic aspects. An intensive participatory ecological survey was undertaken to characterize the Kirisia Forest Reserve as a whole (Hitimana et al., 2009) and a socioeconomic survey within adjacent Group Ranches was also carried out by use of questionnaires. This paper is a consolidation of socio-economic aspects from both studies with a clear linkage between conservation and improving people's livelihoods. That is, the paper focuses on socioeconomic profile of the forest adjacent communities, dependence on forest and forest resources, and impact of this dependence on the integrity of Kirisia forest ecosystem.

\subsection{Study context and objectives}

Adjacent communities continuously define ways of utilizing forest resources in order to meet their basic livelihood needs, which means that roles and values of forests to the local communities are also dynamic in space and time (Warner, 1997). In the Kirisia Forest context, the abundant wildlife and high level dependence of Samburu people on the forest may reduce the carrying capacity of the ecosystem leading to its degradation if no adequate management measures are put in place. So far the Government protects the forest through State employed personnel (forester and forest guards). This system has registered overwhelming failure across the nation which has led the Government to review its strategy under the Forests Act 2005 (GoK, 2005). The current forests law encourages local communities and other stakeholders to participate actively in forest management and conservation jointly with the Government agencies through signed agreements that guarantee, among others, greater and easy access and meaningful sharing of benefits accruing from the well managed resources (Gow, 1992). As prerequisite to such joint agreements, the resource base itself must be known and understood in terms of functions and renewability. It is against the above background that AWF sponsored in-depth participatory ecological and socioeconomic surveys in view to better understand challenges facing this ecosystem's integrity and its role in supporting livelihoods of adjacent communities. Data collection instruments used in this study were designed to capture the above variables with reference to ecological state of Kirisia Forest Reserve. 
Participatory forest management is legally entrenched in the Kenya Forests Act 2005. It involves all stakeholders, particularly the government and organized local communities in the sustainable conservation of the resources with some arrangements on benefits-sharing as authorized under the provisions of the Forests Act 2005, Section IV. Local communities must organize themselves into Community Forest Associations (CFAs). The user rights of the forest by the registered CFAs include extraction of non-wood products, ecotourism and recreational activities and development of community wood and non-wood forest based industries provided that none of the activities conflicts with the conservation of biodiversity (Article 47). Along side a participatory forest management plan as a prerequisite to this form of forest resource governance, empowerment of the local community is also critical.

Objectives of the socioeconomic investigations around the Kirisia Forest Reserve were to: (i) identify the nature and magnitude potential of socio-economic and cultural benefits from the forest; (ii) identify and analyze forest-resource-based conflicts; (iii) package socioecological information to inform the development of a sustainable forest-based resource management and conservation model. Research questions were about the actual and potential use of forest by local communities for: (i) timber and other products commonly extracted from the forest; (ii) bee-keeping; (iii) medicinal plants; (iv) eco-tourism; (v) cultural and religious activities; and (vi) negative impacts of the forest on people and how to mitigate them.

Integrating findings from ecological and socioeconomic investigations provides meaningful insights about the landscape management model to be adopted in order to improve people's livelihoods while conserving natural resources within and outside the Kirisia Forest Reserve; through supporting participatory forest management planning and promoting community-based natural resource management planning in Group Ranches around the Kirisia Forest Reserve.

\section{Materials and methods}

\subsection{Description of the study area}

The Kirisia forest is in Samburu District, Rift-Valley Province, Kenya. Samburu District, between $0^{\circ} 40^{\prime} \mathrm{N}-2^{\circ} 50^{\prime} \mathrm{N}$ and $36^{\circ} 20^{\prime} \mathrm{E}-38^{\circ} 10^{\prime} \mathrm{E}$, covers $20,826 \mathrm{~km}^{2}$ and has many forests on hilltops or plateaus, both gazetted and ungazetted and wooded lands. Kirisia Forest also known as Leroghi (initially 92,000 ha but now less than 78,000 ha) is one of the gazetted State Forests. Ungazetted forests and wooded lands are mostly found on communal land managed under Group Ranch tenure system; the land is under Trust by the Samburu County Council. Kirisia forest is located at an altitude ranging from 2,000 to 2,200 $\mathrm{m}$ above sea level with mean annual rainfall of $600-750 \mathrm{~mm}$ at $1945 \mathrm{~m}$ a.s.l. and the mean annual temperature of between 24 and 33 ${ }^{\circ} \mathrm{C}$ (Jaetzold and Schmidt, 1983). There are three wet rainfall peaks in a year, and two driest months: January and February. According to Jaetzold and Schmidt (1983), the general fertility of the soils in the forest is variable and soils are shallow. The area around the forest is dominated by a complex of well-drained, shallow, black to very dark brown, acid humic, very friable loam soils.

The overall density of Kirisia Forest varied as follows: seedlings ${ }^{2}$ (1537 ha-1), Saplings ${ }^{\dagger}$ (1322 ha-1), Pole-sized treest (196 ha-1 equivalent to $21.2 \mathrm{~m}^{2} \mathrm{ha}^{-1}$ ) and Large treest (86 ha-1

${ }^{2}$ Seedlings $=$ Stems $<1 \mathrm{~m} \mathrm{Ht} ;$ Saplings $=$ Stems $1 \mathrm{~m} \mathrm{Ht}-10 \mathrm{~cm}$ dbh; Pole-sized trees $=$ Stems $\geq 10-20 \mathrm{~cm}$ $\mathrm{dbh}$; Large trees $=$ Stems $\geq 20 \mathrm{~cm}$ dbh 
equivalent to $\left.24 \mathrm{~m}^{2} \mathrm{ha}-1\right)$ (Hitimana et al., 2009). Overall, four species dominate the forest top canopy: Olea europaea ssp africana (up to $34 \%$ ), Juniperus procera (up to 25\%), Podocarpus falcatus (up to $26 \%$ ) and Croton megalocarpus (15\%). Those species dominating the middle canopy all blocks combined were P. falcatus (12-45\%), O. europaea ssp africana (21 -28\%), J. procera (20 \%), Teclea simplicifolia (13-15\%) and C. megalocarpus (12 \%) (Hitimana et al., 2009). Beentje (1990) described floral composition of Kirisia Forest as having different vegetation associations, dominated by large tree species above in addition to Nuxia congesta on much of the hills; and Cassipourea malosana on wetter slopes. Understorey tree species include Teclea nobilis, Maytenus undata, and Acokanthera schimperi and Mystroxylon aethiopicum. The forest is also a mixture of open, disturbed and rocky areas covered with Euclea divinorum, Carissa edulis, Rhus natalensis and Croton dichogamus small trees and shrubs. Regeneration of the tree component is characterized by saplings totaling 1322 individuals per hectare shared among 62 out of 95 tree species recorded above $10 \mathrm{~cm}$ dbh. Overall, 11 species formed the bulk of regeneration in the entire Kirisia forest. Seedlings total 1537 individuals per hectare distributed among 46 tree species among the 95 recorded above $10 \mathrm{~cm} \mathrm{dbh}$. That is, about $52 \%$ of tree species in Kirisia did not have seedlings during the time of the survey. This is a huge deficiency.

The faunal and avi-faunal diversity in Kirisia Forest Reserve is very high throughout the forest. The forest is on overall an important habitat for wildlife, thus a hot spot for biodiversity conservation and a potentially important attraction for tourism development. However, the rich wildlife in the forest cannot be sustainably managed without the integration of the adjacent dispersal areas through the participation of the adjacent Group Ranches and individual land owners. These ranches are crossed by several migratory wildlife routes and corridors (Figure 2) which link major wildlife habitats within the Samburu Heartland.

For communities around the forest, the main land tenure system is communal $(90 \%$ of households; $10 \%$ of households are located either on private land or State owned land in the forest through encroachment). The communal land is divided into Group Ranches, shared by registered members who are allowed to graze or establish homes (manyattas) anywhere. Figure 3 show land tenure context around the forest. The forest is bordered by 13 group ranches and the study focused on all group ranches.

The ownership of the wider Kirisia forest ecosystem is mixed: a community resource and a national resource. The State Forest Reserve is enclosed between community-owned land (Group Ranches) often with unclear demarcations of boundaries. In addition, reports about migratory bird species from as far as Europe and Asia being traced within the forest during some periods of the year, its uniqueness as a habitat and / or corridor for some of the protected wildlife species such as elephants reflect the international interests about this forest in terms of conservation biology. Despite its importance to many, the Kirisia forest ecosystem has no defined management model and is under threat of mismanagement leading to degradation and human encroachment for settlements.

\subsection{Description of the sampled community representatives}

Respondents came from a sample representing all age-categories of heads of households and gender (Table 1). Based on the age and gender structure of the respondents, the views were captured from adult community as a whole and there was fair representation of both age and gender. The group of respondents below 55 years is made of active members in the 

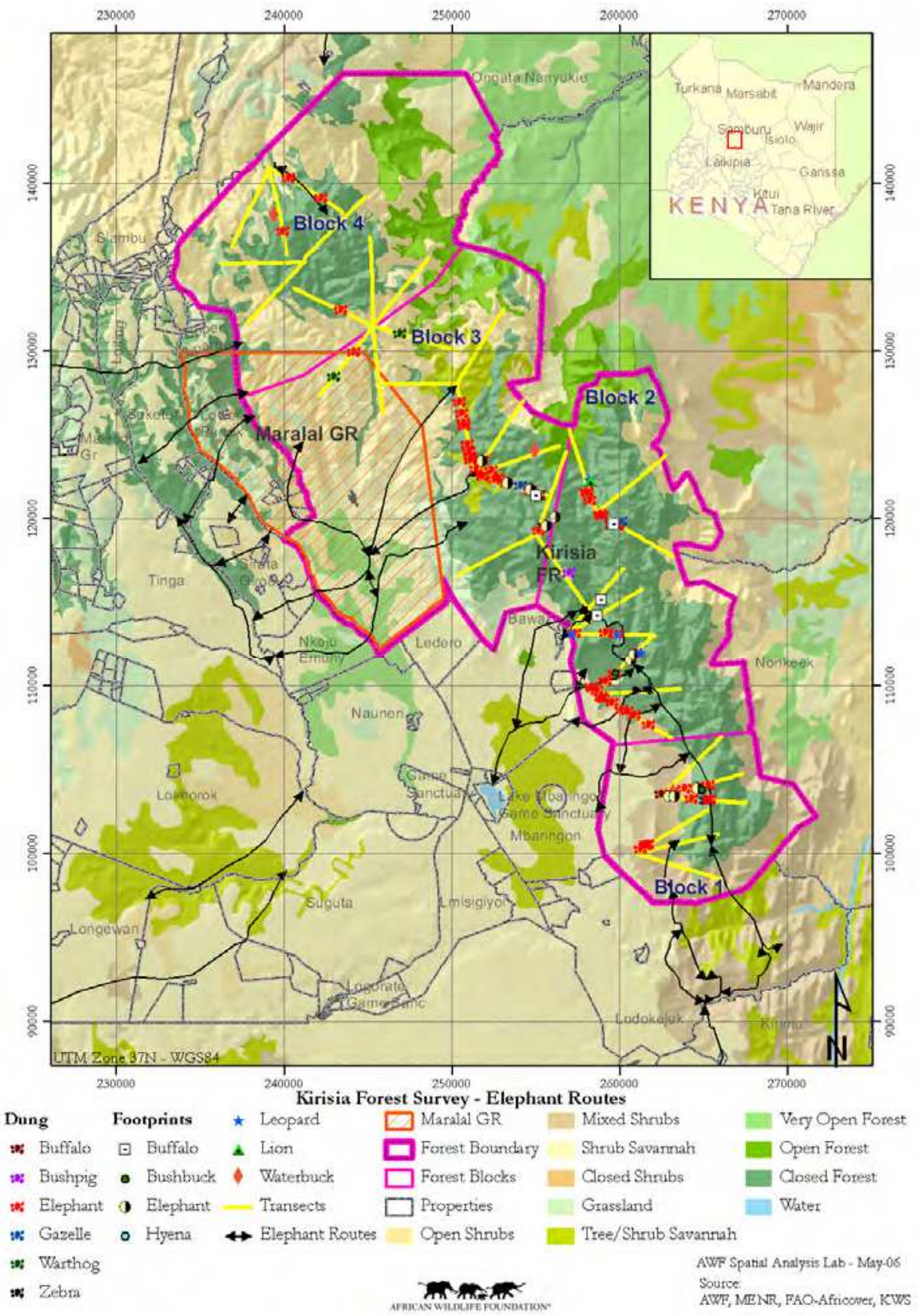

(Source: Hitimana et al., 2009)

Fig. 2. Movement of wildlife within and around Group Ranches west of Kirisia Forest Reserve, Samburu Heartland. 


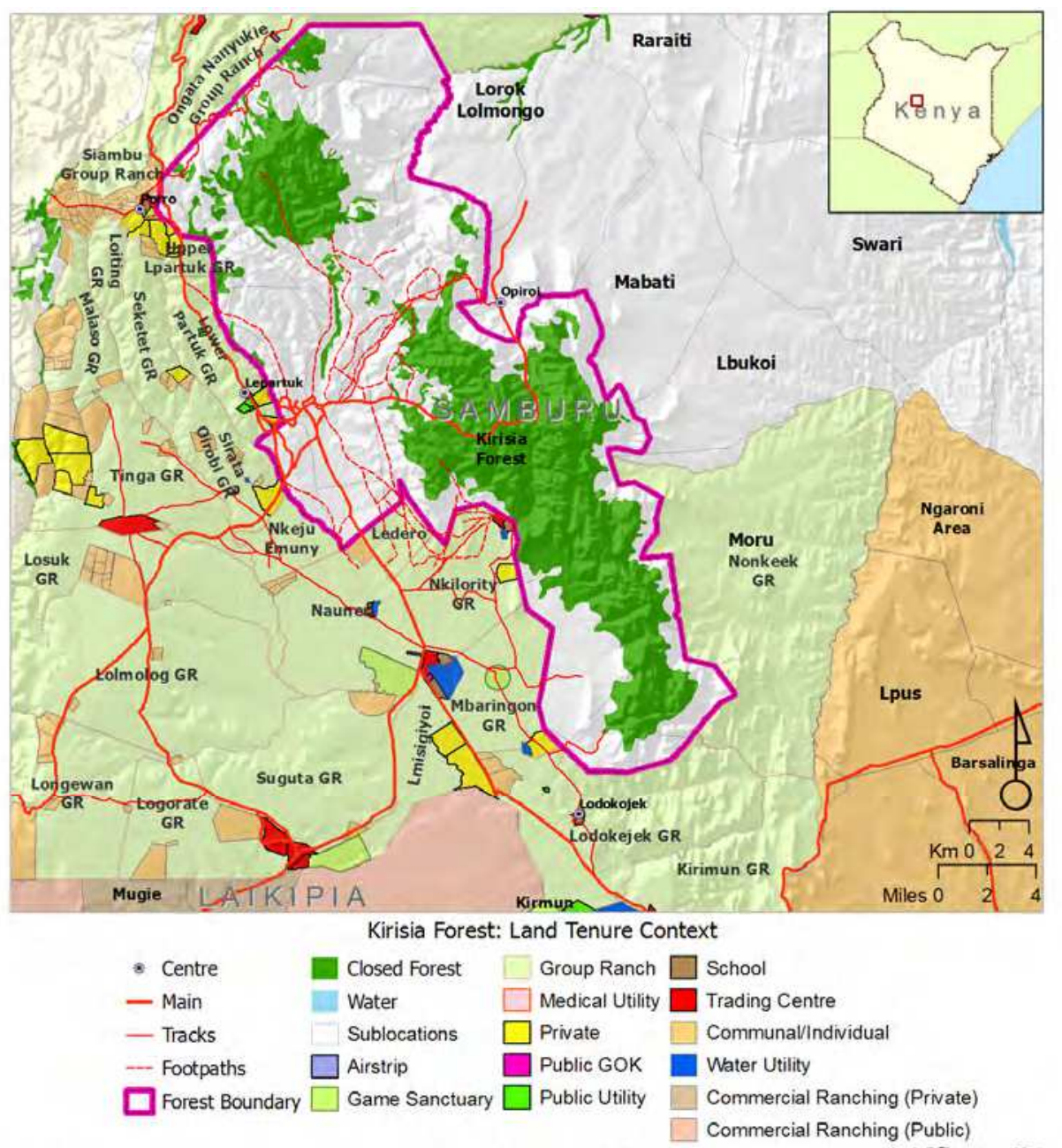

Source:

CBS, Survey of Kenya, AWF, KWS, MENR, FAO-Africover, SRTM-90m

AWF Spatial Analysis Lab

Dec-07

antix

(Source: Hitimana et al., 2009)

Fig. 3. Land tenure context in Group Ranches west of the Kirisia Forest Reserve, Samburu Heartland.

community as far as the country's workforce is concerned. Many households were represented by female (mostly wives) due to the lifestyles whereby male heads of households are out guarding grazing livestock. The general literacy and education levels of the rural Samburu community around Kirisia forest were low.

\subsection{Survey techniques}

Human dependence on the Kirisia Forest Reserve was analyzed through intensive socioeconomic study based on guided personal interviews in the forest and outside, to enhance 


\begin{tabular}{llc}
\hline Parameter & Categories & $\%$ \\
\hline Age class (year) & $25-55$ & 60 \\
& Below 25 & 29 \\
& Above 55 & 55 \\
\hline Sex & Male & 52 \\
& Female & 48 \\
\hline Top education level & Informal & 85 \\
& Primary & 10 \\
& Secondary & 5 \\
& Post-secondary & 0 \\
\hline
\end{tabular}

Table 1. Description of the sampled community representatives.

sustainable forest use and improve livelihoods of forest adjacent communities. Interviews were undertaken in October to December 2005. Socio-economic survey was carried out using structured questionnaires and personal interviews in Group Ranches around the forest. The study focused on all Group Ranches. Cluster sampling was used in selection of the villages. The ranches formed the clusters and the villages were selected on cluster basis and not on individual village basis. Random sampling was then used in the selection of the manyattas and respective households to be interviewed. The survey was carried out on the households adjacent to the forests or within $5 \mathrm{~km}$ radius from the forest edge to generate the primary data to be used for the study. A total of 12 households were randomly selected for each Group Ranch. The study targeted the household heads as the main respondents for the interview, in whose absence an alternative respondent, that is, the next in rank to the household head such as the spouse, a son or a daughter above 18 years of age conversant with forest-based household economy. Informal interviews and discussions with field guides during ecological surveys (Hitimana et al., 2009) provided additional useful socioeconomic data about the resource and people depending on it. Field guides were knowledgeable individuals selected from and by the local communities. Ecological survey covered the entire forest subdivided into four forest blocks. Human activities were observed with 0.02 ha-plots arranged along transects (Table 2; Figure 4). Data were collected along a total of 32 transects (up to $5 \mathrm{~km}$ ) cutting across forest sites and vegetation types.

\subsection{Socio-ecological and socio-economic attributes of interest}

1. Local guides helped to capture information on forest uses, conflicts and species types:

- Evidence of extractions of timber and non-timber forest products e.g. pasture / fodder and guidelines that can be used to regulate such extractions

- $\quad$ Evidence of bee-keeping related activities outside and inside the forest

- List of medicinal plant species used and parts from which medicines are extracted

- Inventory of possible ecotourism ventures that can be developed including those already being practiced: list of unique forest sites, viable trails and associated attractions

- List of socio-cultural uses of the forest and evidence of their impact in conservation 
- $\quad$ Evidence of negative influence of forest to people e.g. human wildlife conflicts

2. Households' heads provided data on social, economic and cultural values attached to the forest.

\begin{tabular}{|c|c|c|c|c|}
\hline \multirow[t]{2}{*}{ Blocks } & \multicolumn{4}{|c|}{ Pre-inventory descriptions } \\
\hline & Located in & $\begin{array}{l}\text { No. of } \\
\text { Transects }\end{array}$ & $\begin{array}{l}\text { No. of } \\
0.02-h a \\
\text { plots }\end{array}$ & Human-forest interface \\
\hline Baawa & Loroki Division. & 6 & 20 & $\begin{array}{l}\text { Adjacent to few human settlements. } \\
\text { Beekeeping and ecotourism are practiced }\end{array}$ \\
\hline Tamiyoi & $\begin{array}{l}\text { Kirisia Division, } \\
\text { between Baawa } \\
\text { and Olpiroi } \\
\text { Dams. }\end{array}$ & 10 & 38 & $\begin{array}{l}\text { Closest block to Marallal Town and } \\
\text { adjacent to high concentration of human } \\
\text { settlements. Beekeeping and high number } \\
\text { of livestock are found in the forest. }\end{array}$ \\
\hline Rapar & Kirisia Division & 10 & 39 & $\begin{array}{l}\text { Adjacent to high concentration of human } \\
\text { settlements. High population of livestock } \\
\text { is found in the forest. }\end{array}$ \\
\hline Nkorika & Kirisia Division & 6 & 25 & $\begin{array}{l}\text { Adjacent to low concentration of human } \\
\text { settlements but high number of livestock } \\
\text { found in the forest. }\end{array}$ \\
\hline Total & & 32 & 122 & \\
\hline
\end{tabular}

Table 2. Pre-inventory description of different sample blocks.

\subsection{Data analysis}

Social, economic and cultural values of the forest for the local communities were described based on informal interviews. The current and potential socio-economic and cultural benefits from Kirisia Forest were analysed and indicated an overall picture of human dependence on the ecosystem in terms of wood and non-wood products. Forest-human interactions were analysed with respect to bee-keeping, harvesting of medicinal plants etc. Human-wildlife conflicts were derived from informal interviews with local guides and local communities in Group Ranches. Mapping and geo-referencing ecological, water and ecotouristic resources within the forest was made as a guide for future development of ecofriendly enterprises to boost livelihoods of local communities. The types of shelters observed and the dominant materials used in putting up the buildings were used as indicators of the wealth status of different households.

\section{Results}

\subsection{Pillars of households economy in group ranches around Kirisia Forest}

There are direct and indirect benefits people derive from forests (Table 3). Livestock keeping is the most dominant primary occupation (Table 4). The Kirisia forest plays a very important role in local people's daily lives by being the main resource for dry season grazing and water for this largely pastoral community. The number of households involved in farming (crop cultivation) as their major occupation was quite higher than expected and had low number of domestic animals (generally less than ten cows per household). Agricultural crops included maize (Zea mays), sorghum (Sorghum bicolor), wheat (Triticum aestivum) and 


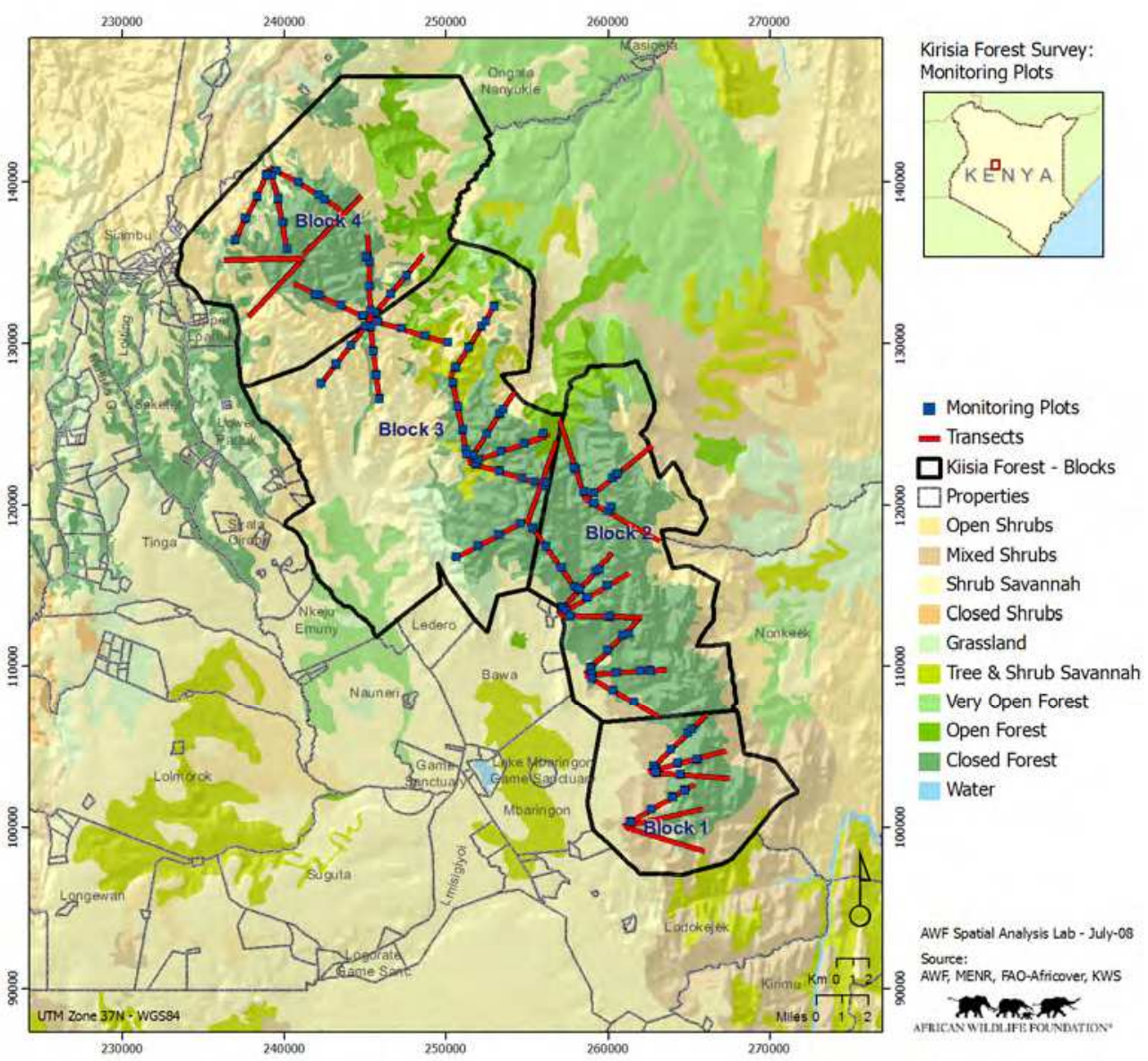

Fig. 4. Distribution of belt transects and sampling plots within Kirisia Forest, 2005 Block IDs: Rapar (Block 1), Baawa (Block 2), Tamiyoi (Block 3) and Nkorika (Block 4) (Source: Hitimana et al., 2009).

other crops that are drought tolerant. Crop growing near the forest - a habitat to high diversity of wildlife including birds and herbivores - is one potential source of wildlife human conflict as crops are often raided and damaged.

A small percentage of households relied on off farm activities as their primary occupation, especially trading and permanent employment such as teachers. The community literally has no alternative source of livelihood; only livestock and farming for those who don't have them as a primary occupation. In view of these findings, by and large, the community's household economy was mainly based on land resource for cultivation or livestock grazing. The forest plays a key role in livestock and agricultural development in the area as a source of water, pasture and fodder particularly during dry seasons. The forest has also been the main source of wood for domestic use (construction and fuel) and rarely for income generation (Table 4). 


\begin{tabular}{lll}
\hline Direct values & Indirect values & Constraints \\
\hline Firewood (Fuelwood and Charcoal) & Rain attraction & Acquisition of \\
Water & Wind breaks & permits \\
Timber and Building posts & Aesthetic value & Policing \\
Fruits & Cultural and religious & Wildlife conflicts \\
Thatching grass & uses & \\
Honey & Water conservation & \\
Medicinal herbs & Wild animal habitat & \\
Traditional tools & Erosion control & \\
Bee hives & & \\
Wild meat & & \\
Grazing and fodder & & \\
Employment & & \\
Eco-tourism & & \\
\hline
\end{tabular}

Table 3. Benefits local people derive from Kirisia Forest, Samburu, Kenya.

\begin{tabular}{lll}
\hline Parameter & Categories & $\%$ \\
\hline Primary occupation & Farming & 35 \\
& Livestock keeping & 60 \\
& Off-farm employment & 5 \\
& Livestock alone & 52 \\
& Farming alone & 40 \\
& Both livestock and farming & 8 \\
\hline Secondary occupation (alternatives) & Farming & 50 \\
& Livestock keeping & 40 \\
& None & 10 \\
\hline Wood for construction & Shelter as wooden houses & 85 \\
& Mud houses & 7 \\
& Stone houses & 8 \\
\hline Source of Firewood & Kirisia State Forest & 78 \\
& Group Ranch & 22 \\
\hline Use of firewood & Commercial & 1 \\
& Domestic & 99 \\
\hline
\end{tabular}

Table 4. Levels of dependence on land and wood for livelihoods for households adjacent to Kirisia Forest, Kenya, 2005.

\subsection{Households dependence on Kirisia Forest}

According to interviews returns, the Kirisia Forest was highly valued by the local people as the source of firewood, pasture, posts, water, medicinal herbs and rain in a descending order (Figure 5). From ethno-botanico-ecological survey additional details of the forest value were noted. Several tree species were identified as source of fodder for livestock, others as high quality bee forage, and others were source of food for humans. Most of the forest products are harvested for household use (Table 5); hence the community does not view the forest as a source of income as much. Posts were used in the construction of manyattas 


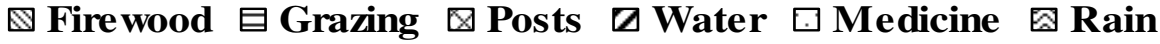

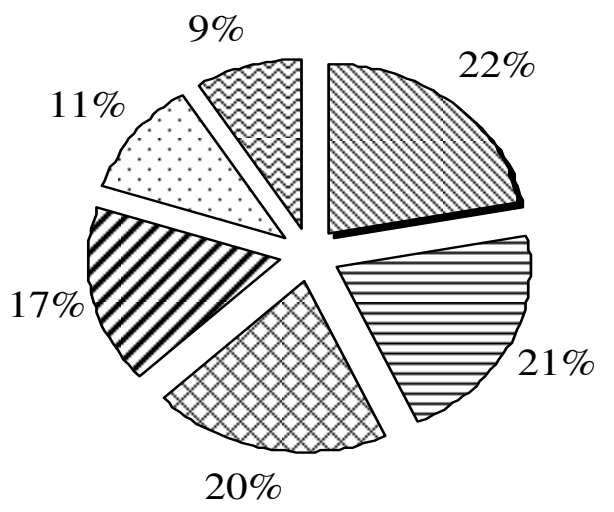

(Source: Interviews with local communities)

Fig. 5. The most important products derived from Kirisia Forest, Kenya, 2005.

(traditional samburu/maasai houses) and for fencing, which very common even in the nearby Marallal town, the single most important market outlet of commercialised forest products from Kirisia. Preferred species for fencing was Juniperus procera due to its durability in the ground and resistance to termites attack. Quite a high percentage of households were involved in herbal medicine as an income-generating activity in local markets. Charcoal making in Kirisia, was seen emerging in the forest blocks near Maralal township (e.g. Tamiyoi block) though it was not mentioned during interviews. Sites of charcoal production (including live kilns) were encountered within the forest, though not many. However, this activity, if uncontrolled and uncoordinated, is potentially a major threat to the integrity of the ecosystem, as urbanization coupled with increasing change in lifestyle of the nomadic pastoral communities continue to set in.

\begin{tabular}{lrr}
\hline Uses of products & Posts & Medicinal herbs \\
\hline Domestic alone & $55 \%$ & $50 \%$ \\
Commercial alone & $10 \%$ & $46 \%$ \\
Both domestic \& Commercial & $35 \%$ & $2 \%$ \\
Undisclosed & $0 \%$ & $2 \%$ \\
\hline
\end{tabular}

Table 5. Percentages of households adjacent to Kirisia Forest that use posts and medicinal plants for domestic or commercial purposes, 2005.

\subsubsection{Pasture / fodder for livestock}

The Kirisia forest plays a very important role in local people's daily lives by being the main resource for dry season grazing and water source for this largely pastoral community. Pollarding of trees for fodder was found common but targeting a few species. About $42 \%$ of damaged tree individuals (187 out of 451), belonging to eight different species, were pollarded for calves or as dry season source of fodder for the livestock; the most popular 
and affected species was Olea europaea ssp africana (Table 6). However, ethnobotanical survey revealed over 16 woody species (Table 7) that were actually recognized by the locals as fodder species; that is, $16.8 \%$ of the 95 tree species identified in the sample plots. It was noted that a few (three) of the commonly known fodder species were target in the "cut-andcarry system" of the dry season intensive exploitation of fodder. The fact that pollarding was observed to many more species than those listed as common fodder species implied that, during dry season, people expand the range of fodder species to include those that are usually not easily accessible e.g. requiring climbing during fodder harvesting. The impact of collecting fodder from palatable tree species through pollarding is exceptionally worrying; it is unprofessional, unplanned and uncoordinated. Table 8 shows the three most frequent damages on trees per block.

\begin{tabular}{|c|c|c|c|c|c|c|c|c|}
\hline \multirow[t]{2}{*}{ Forest Block } & \multirow[b]{2}{*}{\begin{tabular}{|l|} 
Rapar \\
Pollarded \\
trees
\end{tabular}} & \multirow{2}{*}{\begin{tabular}{|l|} 
Baawa \\
$\begin{array}{l}\text { Pollarded } \\
\text { trees }\end{array}$ \\
\end{tabular}} & \multirow{2}{*}{\begin{tabular}{|l|} 
Tamiyoi \\
Pollarded \\
trees
\end{tabular}} & \multirow{2}{*}{\begin{tabular}{|l} 
Nkorika \\
$\begin{array}{l}\text { Pollarded } \\
\text { trees }\end{array}$ \\
\end{tabular}} & \multicolumn{4}{|c|}{ Entire Forest scenario (28.3 ha - sample size) } \\
\hline & & & & & \begin{tabular}{|l} 
Total \\
damaged \\
trees
\end{tabular} & $\begin{array}{l}\text { Pollarded } \\
\text { trees }\end{array}$ & \begin{tabular}{r|} 
\\
Pollarded \% per \\
species
\end{tabular} & $\begin{array}{l}\text { Share of } \\
\text { pollarded trees } \\
\text { among species }\end{array}$ \\
\hline Teclea simplicifolia & 4 & 1 & 0 & 0 & 10 & 5 & 50.0 & 2.7 \\
\hline Olea europaea & 30 & 78 & 31 & 28 & 269 & 167 & 62.1 & 89.3 \\
\hline Grewia tembensis & 1 & 0 & 0 & 0 & 2 & 1 & 50.0 & 0.5 \\
\hline Juniperus procera & 2 & 1 & 2 & 0 & 139 & 5 & 3.6 & 2.7 \\
\hline Croton megalocarpus & 0 & 2 & 0 & 0 & 13 & 2 & 15.4 & 1.1 \\
\hline Euclea schimberi & 0 & 4 & 0 & 0 & 15 & 4 & 26.7 & 2.1 \\
\hline Lamaroki / Lamarogi & 0 & 0 & 1 & 0 & 1 & 1 & 100.0 & 0.5 \\
\hline Ngeriyoi & 0 & 0 & 2 & 0 & 2 & 2 & 100.0 & 1.1 \\
\hline Total & 37 & 86 & 36 & 28 & 451 & 187 & 41.5 & 100.0 \\
\hline$\%$ pollarded per locality & 29 & 49 & 34 & 65 & & 41 & & \\
\hline
\end{tabular}

Table 6. Pollarded species for livestock fodder and other products and magnitude of the practice in Kirisia forest.

\begin{tabular}{|l|l|}
\hline Olea capensis ssp hotchstetteri (Lolionti) - & Mystroxylon aethiopicum (Lodonganayioi / \\
Dry season fodder & Saramonai / Lodonganayai) \\
Olea europaea (Lngeriyoi) - Dry season & Pavetta abyssinica (Ljeni Ebor) \\
fodder & Rhus natalensis (Msigioi / Lmisigiyioi / \\
Carissa edulis (Sangumai / Sakumai / & Lmisigiei) \\
Sagumai/ Lamuriai) & Teclea simplicifolia or Cadia purpurea (Lgirai / \\
Celtis africana (Lekere / Lekiri / Ngisitet & Lgiriyai) \\
/ Nekiri) & Kosintet / Ngositet \\
Dombeya sp. (Lporokwai) & Lamaroki / Lamarogi \\
Erythroccoca bongensis (Leshapirik / & Machakudu / Lcokudu \\
Lechopiriki / Lesopirik) & Ngeni-Niok / Njeni-Nayok \\
Grewia tembensis (Irri / Iriei) & Rhammus staddo for goats \\
\hline
\end{tabular}

Table 7. The 16 fodder tree species recorded during the ethnobotanical survey in Kirisia.

\subsubsection{Human food and hygienic products}

Kirisia Forest is one of the sources of food and other nutrition-related products (Table 9). It is a major source of wild honey used locally and sold in the area. The survey revealed 18 woody species $(18.9 \%)$ from which food and other domestic uses of non-wood forest 
products (NWFP) were collected. Tree species such as Clausena anisata, Teclea simplicifolia or Cadia purpurea (Lgirai / Lgiriyai), Justicia sp. and Calodendrum capense (Larashi) are used for cleaning teeth (toothbrush).

- $\quad$ Rapar Block: - Pollarding (29\%), debarking (23\%) and dead (13\%)

- Baawa Block: - Pollarding (49 \%), Heart $\operatorname{rot}(19 \%)$ and debarking $(8 \%)$

Tamiyoi Block:- Debarking (34 \%), pollarding (31\%), dead (15\%).

- Nkorika Block: - Pollarding (65\%), debarking (13\%) and disease (13\%)

Table 8. Major damages inflicted on trees in Kirisia Forest.

\begin{tabular}{ll}
\hline Nutrition and Hygiene & Species \\
\hline Edible fruits but poisonous leaves & Acokanthera schimperi (Murichoi /Lmorijoi) \\
Edible fruits & Lmai; Lgormoshio; Vangueria madagascarensis \\
Edible gum & Grewia tembensis (Irri / Iriei) \\
Edible seeds & Dovyalis abyssinica (Lmoroo / Moroo) \\
Vegetable leaves & Euclea schimberi or E. divinorum (Nchinyei /Lchingei) \\
Honey unfit for expectant women & Lpinai / Lbenai \\
Aromatic spice & Lominyanyi \\
Appetizer & Lokujok \\
Milk gourd cleaning & Tarenna graveolensis (Lmasei) \\
Stimulant as Aphrodisiac & Longariboi; Lorekiri; Ekebergia capensis (Songoroi) \\
\hline
\end{tabular}

Table 9. Kirisia Forest as a source of human food and other NWFP used in households.

\subsubsection{Beekeeping and honey extraction}

The use of forest as source of honey was apparent from both socioeconomic interviews in Group Ranches and from ethno-botanical survey inside the forest: $70 \%, 10 \%$ and $20 \%$ of households using honey obtained it from the Kirisia Forest, on the Group Ranches land, or purchased from honey gatherers/producers around the forest. From all households that harvested/hunted honey did so for: (i) domestic uses only (54.3\%), income generation only $(2.5 \%)$ or both $(43.2 \%)$. Local people heavily depend on the Kirisia State Forest for honey by collecting wild honey and/or hanging hives inside the forest. Even emerging beekeeping outside the forest (e.g. Group Ranches) using different kinds of beehives still depends on the forest as a habitat for a diversity of bee forage which influence the properties and quality of honey produced, and as a source of permanent water even when all water points have dried outside the forest e.g. during droughts. Popular bee-forage tree species were Mystroxylon aethiopicum (Lodonganayioi / Saramonai), Lpinai, Machakudu/Lcokudu, Lmuzungach and Mukinyeyi. Honey gathering in the wild was the most common method of harvesting honey supplies for households. Modern beekeeping was still at infant stage in the Kirisia area; being practiced by a few progressive beekeepers. The indigenous technique used to harvest honey from forests used fire and felling of trees to access honey up the stem, at a height beyond reach from the ground. This technique is wasteful, very destructive and nonsustainable. Eight species, all of them in the upper canopy, were damaged through honey harvesting using fire and axes (Table 10).The most affected species were Juniperus procera and Olea europaea ssp africana. Promoting efficient beekeeping and honey extraction technologies can play several roles: increased yield and income, and protection of tree 
species otherwise damaged by traditional practices and other components of the ecosystem depending on them.

\begin{tabular}{lcccc}
\hline & \multicolumn{2}{c}{$\begin{array}{l}\text { Damaged trees using axes or } \\
\text { machettes for honey harvesting } \\
\text { from tree stems }\end{array}$} & $\begin{array}{l}\text { Burnt trees during honey } \\
\text { harvesting }\end{array}$ & Total \\
\hline Machakudu / Lcokudu & 1 & 0 & 1 \\
Croton megalocarpus & 0 & 1 & 1 \\
Mystroxylon aethiopicum & 0 & 1 & 1 \\
Teclea simplicifolia & 1 & 0 & 1 \\
Podocarpus falcatus & 1 & 3 & 4 \\
Croton megalocarpus & 1 & 1 & 2 \\
Juniperus procera & 5 & 15 & 20 \\
Olea europaea & 1 & 32 & 33 \\
\hline Total & 10 & 53 & 63 \\
\hline
\end{tabular}

Table 10. Tree species damaged through wild honey harvesting from Kirisia Forest, Samburu, 2005.

\subsubsection{Medicinal plants (herbs)}

Fifty four percent (54\%) of the respondents acknowledged the medicinal value of Kirisia forest to humans. Over $92 \%$ of them collected medicinal herbs solely for domestic uses, $4 \%$ for commercial purposes to generate income and another $4 \%$ for both domestic and commercial. At least 30 species of the 95 recorded woody plant species (over $30 \%$ ) were reported as being of high medicinal value, used by local people in herbal medicine to treat diverse ailments (Table 11).

Herbs were also used to treat livestock e.g. de-worming (Olea europaea), placenta removal after birth (Olinia rochetiana) and tapeworms (Lorekiri). Calodendrum capense produces a perfume. Kirisia area remains a potential research site for further investigations in how to promote herbal medicine for biodiversity conservation and improved livelihoods of local people. This aspect is a strong entry point in joint / participatory forest management scheme.

Different parts of the plant were harvested as medicinal: leaf extract (Justicia sp., Trimeria grandifolia), Bark extract (Croton megalocarpus, Juniperus procera, Mystroxylon aethiopicum, Olinia rochetiana, Lokujok, Podocarpus falcatus, Vangueria sp, Lorekiri, Trimeria grandifolia), Root extract (Trimeria grandifolia, Rhamnus prinoides (concoction), Rhammus staddo, Carissa edulis, Croton dycotomous, Dombeya sp., Euclea schimberi /E. divinorum, Rhus natalensis, Teclea simplicifolia / Cadia purpurea, Toddalia asiatica, Euphorbia candelabrum, stem or twig sap (Euphorbia candelabrum, Aloe secundiflora), fruits (Myrsine africana). The harvesting of barks, roots and stems is a threat to plant life and potentially not sustainable. There is need to promote low impact harvesting technologies and other conservation measures to protect threatened medicinal plants, both inside and outside the forest. 


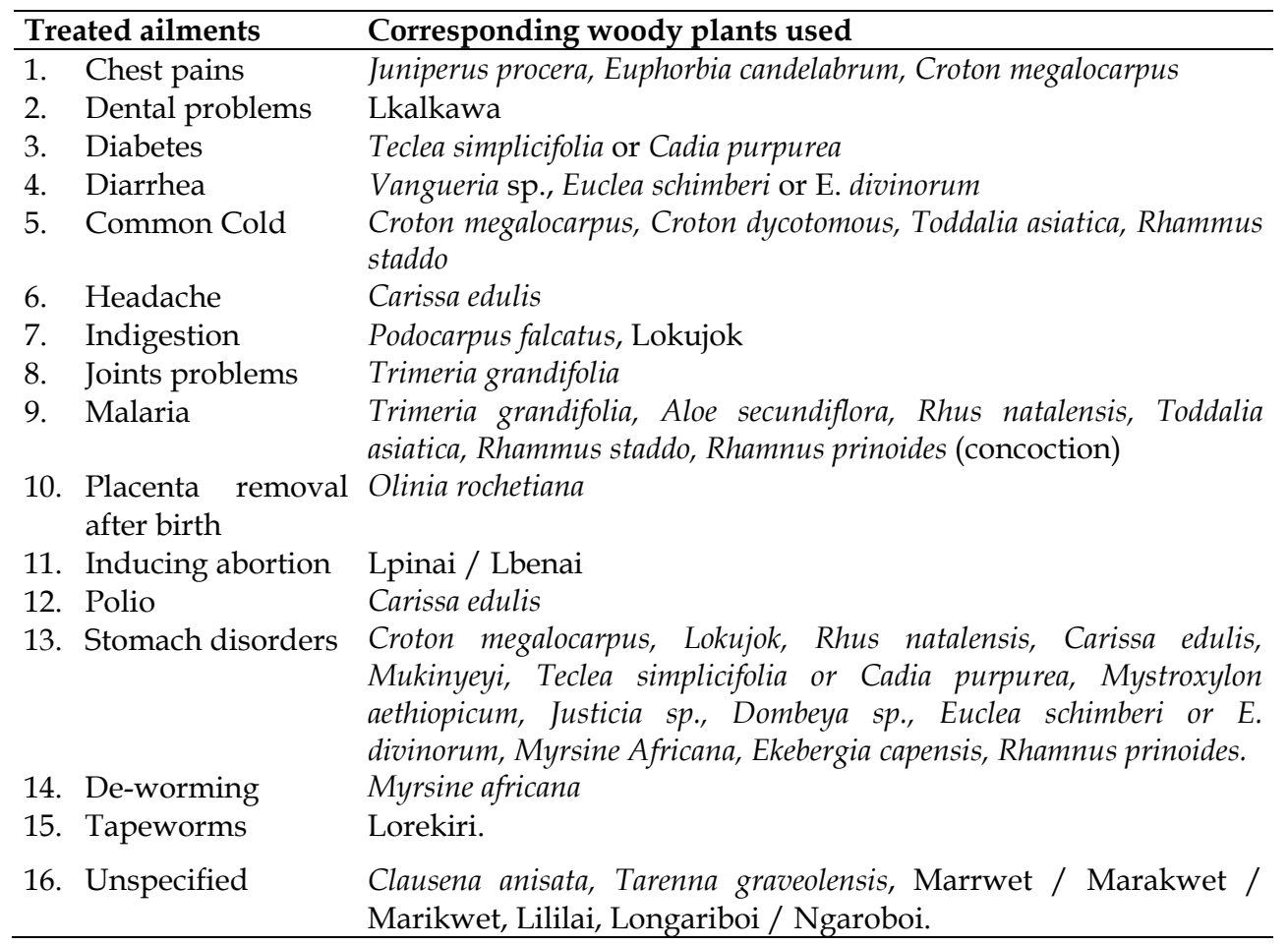

(Source: Personal interviews with local people, 2005)

Table 11. Herbal woody plant species recorded in Kirisia forest based on indigenous knowledge, 2005.

\subsection{Cultural value of the forest to local communities}

The Samburu community attaches strong cultural value to the Kirisia forest and tree resources in general. Different forest plants and plant parts are used in various cultural ceremonies (Table 12). Birds constitute an important forest-based natural resource used in ceremonies and that also attract bird-watching tourism. Conservation measures including community sensitization should be put in place to minimize destructive uses of bird resource e.g. killing to collect feathers for traditional ceremonies such as boys' circumcision, and instead optimize income accruing from bird-based ecotourism and research.

\subsection{Ecotourism development opportunities}

Ecotourism development is an important nature-based enterprise that can significantly generates income from both local and international visitors to Kirisia area and its environs, benefiting not only the State but also local people. Local people benefit from ecotourism in various ways: employment as tour guides, as owners of camping sites, availability of market (buyers) for local artists, booming business in the hotel industry (guest houses).

The Kirisia forest and the surrounding landscape are rich in wildlife and other attractive features. The presence of this closed canopy forest within a dryland region is an attraction 
in itself. The forest rich biodiversity in terms of plant types and animal life (mainly mammals and birds) is quite attractive. Such benefits motivate beneficiaries in conserving the resource base for the ecotourism enterprise. Figures 6 and 7 mapped spatial distribution of animal wildlife and other attractive features within the Kirisia Forest Reserve, Samburu, Kenya, 2005.

\begin{tabular}{|c|c|c|c|}
\hline Events & Plant use & Plant species & Plant parts used \\
\hline \multirow[t]{5}{*}{ Circumcision } & Symbol of blessing & Ltarakwai & Branches \\
\hline & Making fire & Sucha & Leaves \\
\hline & Symbol of peace & Lchingei & Branches \\
\hline & Symbol of ceremony & $\begin{array}{l}\text { Lgeriyoi, Lgilai, Lkukulai, } \\
\text { Silapai, Tepes, Girigira }\end{array}$ & Branches \\
\hline & & Ngerie & $\begin{array}{l}\text { Leaves and } \\
\text { branches }\end{array}$ \\
\hline \multirow[t]{2}{*}{ Marriage } & Symbol of blessing & $\begin{array}{l}\text { Lgeriyoi, Ltarakwai, Lgilai, } \\
\text { Lkukulai }\end{array}$ & Branches \\
\hline & $\begin{array}{l}\text { Incense for good } \\
\text { smell }\end{array}$ & Nasungoyo & Leaves \\
\hline Sacrifices & Symbol of peace & Ltarakwai, Lkukulai, Lgilai & Branches \\
\hline
\end{tabular}

Table 12. Socio-cultural uses of the Kirisia Forest plants by Samburu community, Kenya.

\subsubsection{Wildlife richness in Kirisia Forest}

During the ethno-ecological survey, local guides assisted to identify animal wildlife resources existing in the forest based on evidences such as footprints, feaces, and carcasses of dead animals, sounds, sighting and damages to plants. The faunal and avi-faunal diversity in Kirisia Forest Reserve was very high (herbivores, carnivores, birds, insects) throughout the forest as revealed by several indices (Figure 7). The forest provides fodder / food to herbivores (grazers and browsers), granivores (seed or grain-eaters), fruigivores (Fruits-eaters), carnivores etc. A high diversity of grazers is found in forest gaps (glades) and under open canopy. Similarly, there are carnivores surviving on the different types of the first consumers.

Samburu pastoralists have a very rich indigenous knowledge about the Kirisia forest resources owing to the fact that they have coexisted with and depended on the forest from time immemorial. Trees play an important role in the nutrition of wildlife. Nine tree species out of 95 were recorded as source of fodder for wildlife (Table 13). The checklist of wild animals living in the forest (presence / absence records from the October - November 2005 survey) is annexed (Appendix A) as well as over 60 species of birds encountered and identified in the surveyed parts of the forest (Appendix B)

\subsubsection{Forest disturbance by wildlife: An opportunity costing of ecotourism}

Forest disturbances associated with animal wildlife included debarked by elephants, defoliation/browsing by elephants and other browsers, injuries (including breaking and falling / uprooting) by buffalos and elephants mainly, and death (dying and dead trees) mainly as a result of excessive debarking or burning for honey collection. In the surveyed area (28.3 ha sample), a total of 17 species were found damaged by wild animals, with a magnitude of 198 out of a total of 475 individual trees damaged by different kinds of factors (i.e. 7 out of 17 damaged trees / ha; $41 \%$ ) (Table 14 ). 


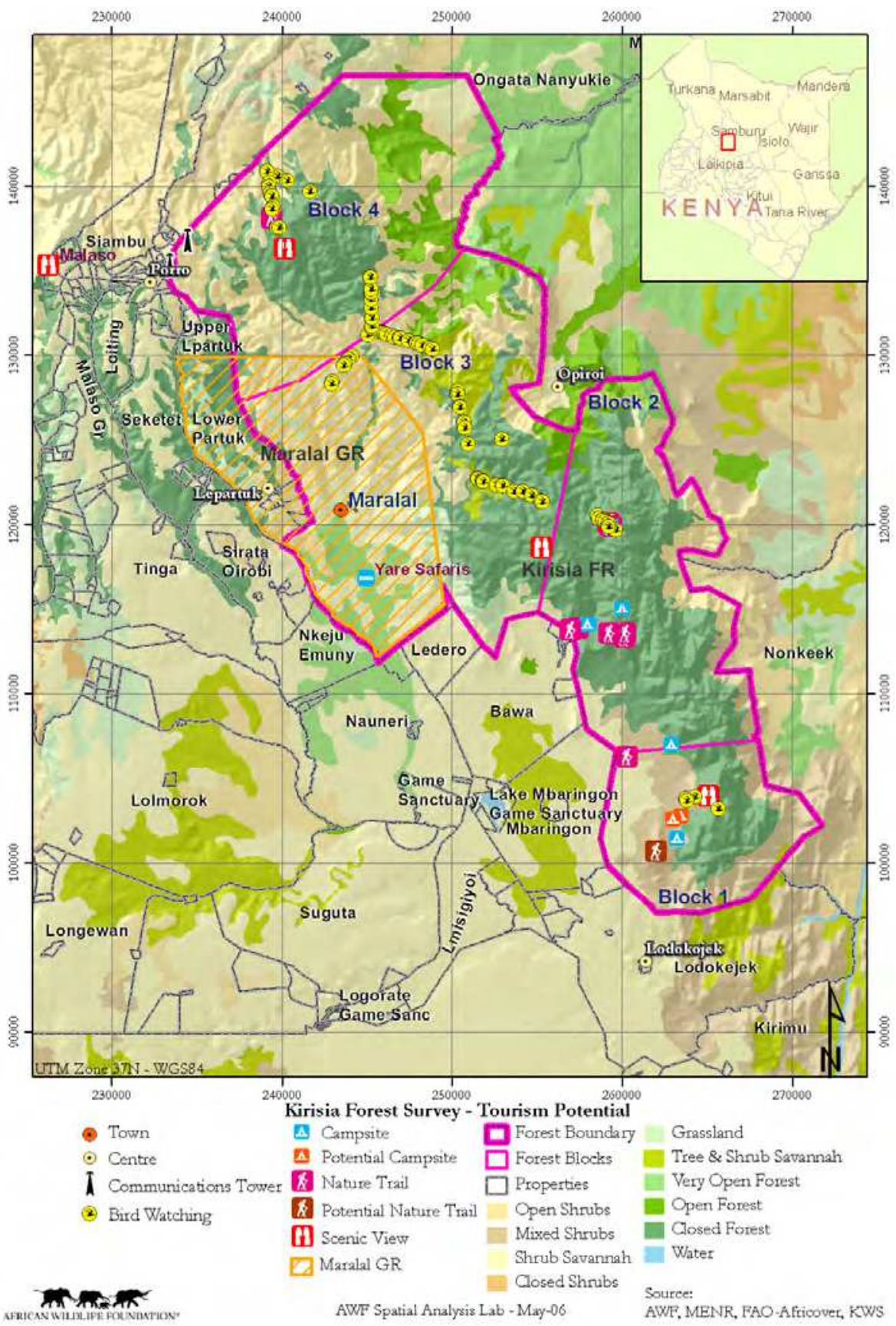

Fig. 6. Mapped spatial distribution of ecotouristic attractive features within the Kirisia Forest Reserve, Samburu, Kenya, 2005. 


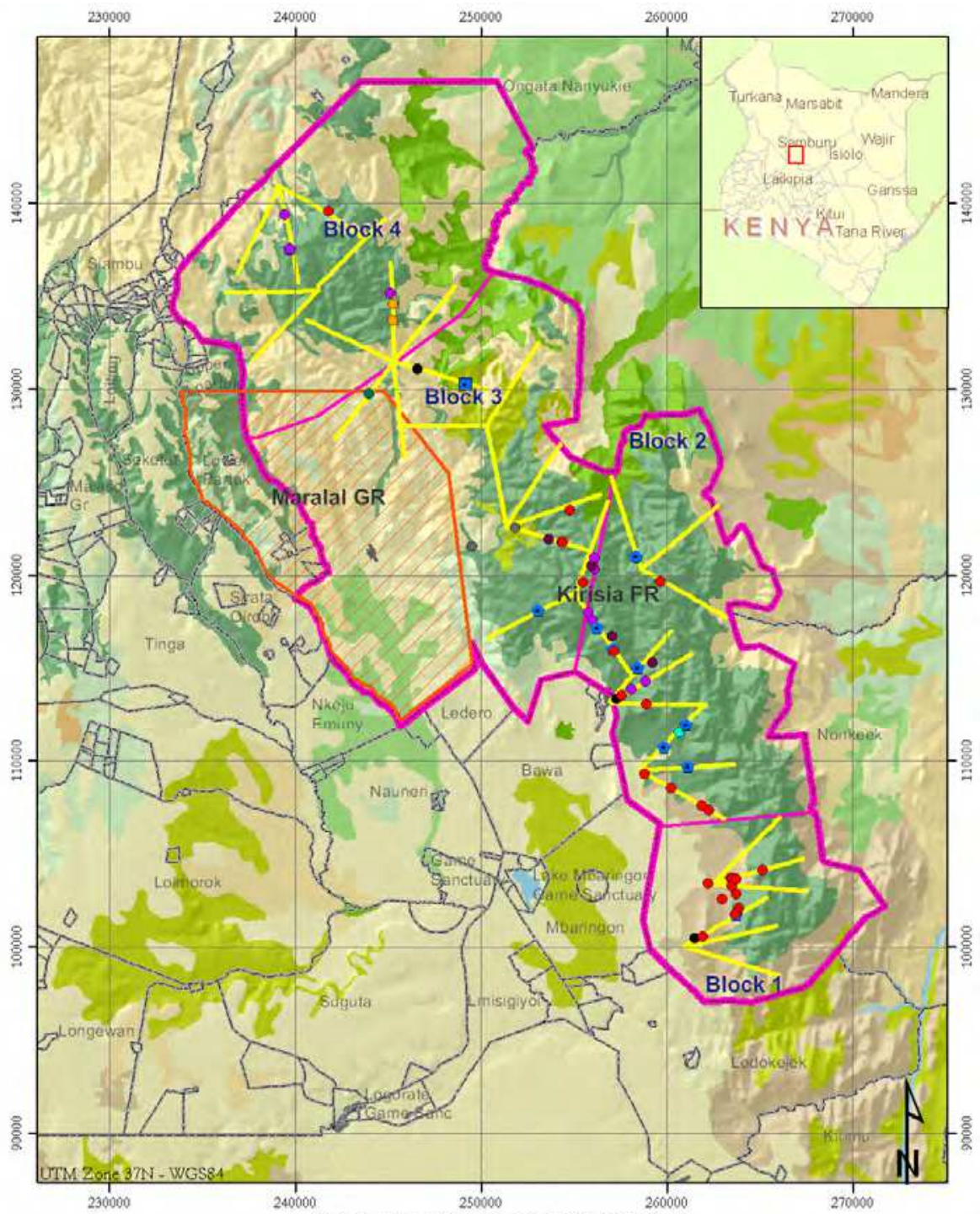
- Antelope - Bushbuck
- Ardvaack - Dikdik
Whathor Open Shrubs
Tree \& Shrub Savannah
- Baboon Eland
- Wildpig $\square$ Forest Boundary
Enixed Shrubs
Very Open Forest
- Buffalo - Elephant
- Zebra
$\square$ Forest Blocks
AWF Sparial Analysis Lab - May-06
Shrub Savannah Open Forest
Closed Shrubs
Grassland
Water
Source:
AWF, MENR, FAO-Africover, KWWS

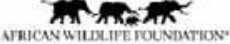

Kirisia Forest Survey - Wildlife Sightings

Fig. 7. Spatial distribution of animal wildlife within the Kirisia Forest Reserve, Samburu, Kenya, 2005. 
The most affected species were Juniperus procera (51\%) and Olea europaea ssp africana (29\%) through debarking and other injuries, often resulting in death of trees. Besides direct physical damage on trees, large populations of elephants, buffalos and other herbivores for wildlife and cattle for livestock affected the Kirisia ecosystem through trampling and destroying regeneration. The survey in plots indicated that the area of permanent paths and animal trails was on average $135 \mathrm{~m}^{2}$ / ha. That is, 1.4\% (range: $0.6-2.1 \%$ ) of land surface were rendered unproductive through trampling (Table 15).

Damages inflicted on the ecosystem integrity as a result of wildlife can be viewed as a component of ecotourism opportunity cost, at least on the ecological side.

\begin{tabular}{|l|l|l|}
\hline Wildlife & Feeding type & Woody species \\
\hline Elephants & Browsing & $\begin{array}{l}\text { Euclea schimberi or E. divinorum (Nchinyei / Lshingei/ } \\
\text { Lchingei/Ljenyei), Trichocladus ellipticus (Balagalagi / } \\
\text { Lpalagilagi, Calidendrum capense (Larashi) }\end{array}$ \\
\hline & Debarking & Teclea simplicifolia or Cadia purpurea (Lgirai / Lgiriyai) \\
\hline Birds & Fruit eating & $\begin{array}{l}\text { Acokanthera schimperi (Murichoi / Lmurijoi/ } \\
\text { Murujoi/Lmorijoi) }\end{array}$ \\
\hline Monkeys & Seed eating & $\begin{array}{l}\text { Turraea parvifolia (Ltunturi / Njeniarok / Nchinioik), Rhus } \\
\text { natalensis (Msigioi / Lmisigiyioi / Lmisigiei) }\end{array}$ \\
\hline Browsers & Browsing & Celtis africana (Lekere / Lekiri / Ngisitet / Nekiri) \\
\hline
\end{tabular}

Table 13. Fodder and food for wildlife animals in Kirisia Forest, Samburu, 2005.

\section{Discussion}

\subsection{Demand side (forest utilization issues)}

\subsubsection{Kirisia Forest as source of water and dry season pasture and fodder}

The many non-wood uses of the forest offer great opportunities for benefit-sharing between the State and local communities as a component in participatory forest management. Tree species are harvested or damaged due to their value in human life: charcoal production, grazing, tree pollarding, honey harvesting, and logging for posts. The Kirisia forest is indeed one of the major water towers in the larger Samburu-Laikipia landscape. Data on water sources and associated drainage systems revealed a high number of dry riverbeds (45) indicative of the existence of many seasonal rivers. A few (15) permanent rivers and springs were found still flowing and there were several (17) water points and wells (highly frequented by people and the wild game mainly elephants and buffalo) and one swamp. Water resources are well distributed across the ecosystem.

\subsubsection{Harvesting of large sized trees}

Despite the presence of large-sized trees in the forest, Samburu community does not extract timber from the forest because it is illegal. Unauthorized splitting of cedar (Juniperus procera) posts for fencing and shelter construction was encountered in the forest, mainly close to settlements. Tree felling for charcoal production occurred in the Forest block nearest to Marallal town, Tamiyoi. Generally, these kinds of extractions were low but could lead to devastating consequences. Data indicated that, by and large, household economy for the 


\begin{tabular}{|c|c|c|c|c|c|c|c|c|}
\hline \multirow{2}{*}{$\begin{array}{l}\text { Species } \\
\text { Acokanthera sch. }\end{array}$} & \multirow{2}{*}{$\begin{array}{r}\text { Debarked } \\
1\end{array}$} & Death & Defoliated & Injured & $\begin{array}{l}\text { Total } \\
\text { W/L } \\
\text { damages }\end{array}$ & \multicolumn{3}{|c|}{$\begin{array}{cc}\% & \\
\text { damages } & \mathrm{W} / \mathrm{L} \\
\text { caused } & \text { damage } \\
\text { by W/L } & \text { share } \% \\
\text { All on each } & \text { among } \\
\text { damages species } & \text { species }\end{array}$} \\
\hline & & 0 & & 0 & 1 & 1 & 100 & 0.5 \\
\hline Celtis africana & 0 & 0 & & 0 & 1 & 2 & 50 & 0.5 \\
\hline Croton meg. & 4 & 2 & & 0 & 9 & 13 & 69 & 4.5 \\
\hline Ekebergia cap. & 0 & 1 & & 0 & 1 & 1 & 100 & 0.5 \\
\hline Euclea sch. & 2 & 1 & & 0 & 6 & 15 & 40 & 3.0 \\
\hline Ficus thon. & 1 & 0 & & 1 & 2 & 5 & 40 & 1.0 \\
\hline Juniperus proc. & 62 & 26 & & 0 & 101 & 139 & 73 & 51.0 \\
\hline Lorekiri & 0 & 0 & & 1 & 0 & 1 & 100 & 0.5 \\
\hline Lkukut & 0 & 1 & & 0 & 0 & 1 & 100 & 0.5 \\
\hline Machakudu & 0 & 1 & & 0 & 0 & 2 & 50 & 0.5 \\
\hline Marrwet & 0 & 0 & & 0 & 1 & 1 & 100 & 0.5 \\
\hline Mystroxylon aeth. & 1 & 3 & & 1 & 0 & 5 & 100 & 2.5 \\
\hline Ngeni-Niok & 0 & 1 & & 0 & 0 & 1 & 100 & 0.5 \\
\hline Olea cap (hotch) & 1 & 0 & & 0 & 0 & 2 & 50 & 0.5 \\
\hline Olea europaea & 11 & 32 & & 1 & 57 & 269 & 21 & 28.8 \\
\hline Podofalc. & 3 & 0 & & 0 & 3 & 7 & 86 & 3.0 \\
\hline Teclea simpl. & 0 & 1 & & 0 & 2 & 10 & 30 & 1.5 \\
\hline Total & 86 & 69 & 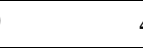 & 4 & 198 & 475 & 42 & 100.0 \\
\hline$\%$ WL damages & 43 & 35 & & 2 & 100 & & & \\
\hline
\end{tabular}

Table 14. Types and magnitude of harm caused on woody plants by animals in Kirisia Forest, 2005.

\begin{tabular}{lrrrr}
\hline Blocks & $\begin{array}{r}\text { Sample Area } \\
(\mathrm{ha})\end{array}$ & $\begin{array}{r}\text { Area footpath/animal } \\
\text { trails }\left(\mathrm{m}^{2}\right)\end{array}$ & $\begin{array}{r}\text { Area trampled } \\
\left(\mathrm{m}^{2} / \mathrm{ha}\right)\end{array}$ & $\begin{array}{r}\text { \% surface area } \\
\text { trampled }\end{array}$ \\
\hline Rapar & 0.40 & 36.5 & 91.2 & 0.9 \\
Baawa & 0.76 & 157.9 & 207.8 & 2.1 \\
Tamiyoi & 0.78 & 45.0 & 57.7 & 0.6 \\
Nkorika & 0.50 & 90.2 & 180.4 & 1.8 \\
\hline Total & 2.44 & 329.6 & 135.1 & 1.4 \\
\hline
\end{tabular}

Table 15. Extent of footpath and animal trails in Kirisia Forest Reserve, Samburu - 2005. 
Samburu people is mainly based on land resource for cultivation and livestock keeping. However, the dependence of Samburu people on Kirisia is still high despite the increasingly changing lifestyle from pure pastoralism to mixed land uses. The forest plays a key role in livestock and agricultural development as a source of water and grazing land particularly during dry seasons.

\subsubsection{Fodder and food value}

Pollarding of Olea europaea (O. africana) was overwhelming throughout the forest with $62 \%$ of all damaged individuals being so through pollarding. Pollarding is manly done by harvesting the crown biomass by overtopping the tree for fodder, firewood, posts or all types of products. During drought or prolonged dry seasons, the herbaceous plants outside the forest disappear and grass dries up.

\subsubsection{Charcoal}

This sector needs to be carefully organised and controlled around the Kirisia Forest but not within the ecosystem itself. As reported by Girard (2002), zones of high concentration of commercial activities and those around urban centres are places with intensive utilisation of wood-fuel; and in such areas, there is an increasingly shifting from fuelwood to charcoal for domestic cooking and heating. High fuelwood and charcoal consumption coupled with weak supply sources put a lot of pressure on existing tree resources (mainly forest in such areas as Samburu where tree cover outside forest is low and manly preserved as shade trees or for fodder), resulting in severe climatic conditions. It is a fact that charcoal, more than fuelwood, is often produced from forest resources than scattered trees off-forests.

\subsubsection{Honey}

As source of income, honey prices per kilogramme were investigated per season for each household (MKK, 2005). Honey is domestically used but it is mainly produced for income generation. The average honey production was found to be $48 \mathrm{Kg}$ per year per beekeeping household; and on average the honey fetched Kenyan Shillings129 which is equivalent to US\$ 1.6 per kg. Total annual income from honey became Kenyan Shillings 6,192 (US\$ 77.4). The average net discounted income per household was Kenyan Shillings 3,301 (US\$ 41.2) (MKK, 2005). It is anticipated that this income would increase if improved techniques of apiculture and value addition were adopted and marketing strategies were put in place. Nevertheless, a lot of improvement is required to modernise the sector such as training to acquire new skills, use of improved equipment such as modern hives and harvesting gear.

\subsubsection{Medicinal value}

Different tree species have been mentioned by the local communities to treat different human ailments except in a few cases where a disease like malaria is treated using several species separately or through mixed concoction. A complete list of diseases based on this work and Watai and Gachathi (2003) for the same Forest includes:

1. Asthma (2 species)

2. Anemia (Blood shortage) (2 species)

3. Bone problem (1 species) 
4. Chest problems (2 species)

5. Common cold (5 species)

6. Coughing (1 species)

7. Deworming livestock (1 species)

8. Diabetes (1 species)

9. Diarrhea (1 species)

10. Eye problems (2 species)

11. Joint problems (2 species)

12. Malaria (10 species)

13. Polio (1 species)

14. Removal of placenta after birth (1 species)

15. Sexually transmitted diseases (1 species)

16. Stomach disorders (14 species)

17. Throat problems (3 species)

18. Tuberculosis (3 species)

\subsection{Supply side (production issues)}

\subsubsection{Water sources and associated drainage systems}

The high number of dry riverbeds encountered during the survey showed that Kirisia Forest has many seasonal rivers. A few rivers were found still flowing. Several water points were also found and were highly frequented by wild game mainly elephants and buffalo. The Kirisia forest is indeed one of the major water towers in the larger Samburu-Laikipia landscape. Data on water sources and associated drainage systems revealed a high number of dry riverbeds (45) indicative of the existence of many seasonal rivers. A few (15) permanent rivers and springs were found still flowing and there were several (17) water points and wells (highly frequented by people and the wild game mainly elephants and buffalo) and one swamp. Water resources are well distributed across the ecosystem. Most of the forest products are harvested for household consumption (Figure 7); hence the community does not view the forest as a source of income as much as the source of sustenance. For instance, the public forest is the major source of firewood and construction and fencing posts; most of which being used for subsistence (Figure 8).

\subsubsection{Ecotourism}

The forest has very high potential for ecotourism development owing to its high richness and diversity in wildlife and other scenic, physical features. Major wildlife corridors and eco-tourism attractions in Kirisia Forest were recorded and documented with GIS Database at AWF. In all blocks, high variability in vegetation cover from herb layer to forest tree canopy led to high diversity of habitat for animal life. The entire forest ecosystem is unique and an integral conservation strategy is required for sustained biodiversity conservation. The mapping out and protection of critical micro-habitats for diversity conservation would assist in the management of ecotourism in this forest. It is quite important to safeguard the integrity of Kirisia forest also owing to its important catchment value in the region. The Kirisia forest richness in medicinal plants and bee forage is already being positively exploited by local people despite some policy challenges such as lack of clear national policy incentives for herbal medicine. However, with the Forest Act 2005 encourages local communities to participate in the management of State and Local Authority forests through 
Community Forest Associations. Structured bee keeping and herbal medicine activities can therefore form good entry points to forge a Government-Local people partnership in conserving Kirisia Forest. Other eco-friendly enterprises that would be promoted include camping sites, afforestation of degraded areas, organised commercial tree seed collection from economically important tree species such as Croton megalocarpus (e.g. for timber and biodiesel) and Olea europaea and Podocarpus species (for timber) and other species that Kenya Forest Seed Centre of the Kenya Forestry Research Institute may be interested in. Other local and international bodies dealing with tree genetic resources may also finance the collection and preservation of germplasms of threatened species and those of high medicinal values once they are identified.

\subsubsection{Forest as habitat to wildlife and attraction for eco-tourism development}

Both species, Juniperus procera and Olea europaea ssp africana seriously damaged by wildlife, dominate the upper canopy of the forest and their depletion is a major threat to the Kirisia ecosystem. There is high diversity of birds and animals due to different habitat types within the Kirisia forest. Though no snake was seen during the survey, local guides testified that both large and small snakes, poisonous and non-poisonous do exist in the forest. For example, during this survey, a long Cobra (over $1 \mathrm{~m}$ long) was shot dead by KWS rangers at their Camp next to Baawa block. In this study it was difficult to determine endemic forest species (animals and birds). However, the overwhelmingly high diversity of birds' populations showed the need to conserve the Kirisia Forest Reserve as a critical habitat for birds hence making it one of the Important Bird Area (IBA) in the country.

\subsubsection{Kirisia Forest as source of wood}

Out of the 95 tree species, 47 (i.e. $49 \%$ ) were recorded in the timber-sized stage; an indication that a good number of tree species in the Kirisia forest can reach large diameters at maturity. However, only 33 tree species out of the $47(14 \%)$ were represented in the pole-size category. Their populations were on decline, particularly Juniperus procera population. The ageing and declining J. procera population paved way to other species like Teclea simplicifolia. Juniperus procera's high representation at Tamiyoi in the pole stage may be as a result of high fire incidence which may have favoured the J. procera regeneration as a pioneer species, whose seed dormancy is broken by heat. The density of seedlings and saplings varied among the four blocks; it was satisfactory at Rapar and Baawa but very low in Tamiyoi and Nkorika. Logging in natural forests is not the primary management objective in Kenya. If introduced, it would be very destructive and unsustainable in Kirisia forest. Few species dominate in the upper canopy and all produce high quality timber with established markets both locally, nationally and internationally. Logging in the forest would target the same species and destroy the forest structure, leading to destabilization of the ecosystem. Suffice to note the regeneration level of the upper canopy species is very low (Hitimana et al., 2009). However, the growth of trees to huge sizes as observed in this dry forest was a revelation of hope in forestry. On average, the number of timber-sized trees and basal area per unit area reflected a productivity value slightly higher than that recorded in the Mt Elgon Lower Montane Forest (Hitimana et al, 2004) with similar elevation range. The highest density (108 trees / ha) and basal area (32 $\left.\mathrm{m}^{2} / \mathrm{ha}\right)$ recorded in Nkorika Block was comparable to that of the most productive site found at Mt Elgon and South Nandi forests in high potential areas of western forest region of Kenya (Hitimana et al., 2004; Njunge, 1996). These forests however 
suffered much more stiff commercial logging activities in the past than Kirisia but less wildlife damage. Nevertheless, the data showed that plantation forestry as a land use is feasible on the Kirisia site particularly on communal land adjacent to the forest and similar environments as long as well adapted tree species or varieties are used and adequate protection of trees against animals, fire, pollarding and illegal tree cutting is provided. Kenya Forestry Research Institute and other competent institutions such as universities are encouraged to enhance plantation forestry research in such low rainfall areas. At the same time, local communities should be sensitized to embrace integrated land use planning and set aside land (private or communal) for tree planting targeting useful products. The success of tree planting activities would reduce human pressure on the Kirisia ecosystem by providing a buffer and would enhance environmental services such as soil and water conservation, carbon sequestration, and climate regulation in the area.

\subsubsection{Beekeeping, honey hunting and food products}

The Kirisia State Forest is a major habitat for bees and a main source of honey for the locals either from beehives hangs in the forest or from wild honey obtained from colonized tree hollows, rocks etc. The purchased honey also originates from the forest. The role and potential of Kirisia forest as critical source of nectar, water makes an ideal site for hive placement. Most households locate their hives in their homestead but others locate them in/on the border of the forest even though the State outlaws it (MKK, 2005). Once the Forest Act 2005 is fully implemented, such activity will be legalised and well coordinated. The percentage of hives in the forest will definitely increase significantly. The use of Kirisia forest as source of food was revealed by the high number of species reported to produce edible fruits. They are mostly relied on by shepherds or households during famine periods. According to Falconer and Arnold (1989), the role of trees in food security occurs in several ways: supplementing farm production, filling in seasonal shortfalls in food and income, providing a buffer during hardship periods, and income earned from forest-based activities which are sometimes invested in agricultural assets such as livestock. A well managed forest offers the poor a means for investment in their future; an opportunity to escape or break from the cycle of poverty.

\subsubsection{Medicinal value}

The medicinal value of the Kirisia forest to local communities is immense. Statistics provided by this study are just indicators of a huge potential and reveal the need for further investigations in Non-timber forest products from the forest. Specifically, for herbal medicine, many resources exist in non-woody and climbing plants that were not covered in this survey. To illustrate this, 45 species out of 65 (that is, 69\%) reported in Watai and Gachathi (2003) as having medicinal value were not recorded in this study. Different parts of the plant are used: Bark (9 species), Fruits (1 species), Leaves (8 species), Roots (28 species), and Stem (8 species). The medicinal value of the Kirisia forest is very high. Different types of diseases are treated using extracts from roots, stems, fruits, leaves and bark. Similar observations were earlier made by Watai and Gachathi (2003).

In summary, the Kirisia Forest is a valuable extension of adjacent communities' natural resource base. They extract fuelwood, grazing, wood for fencing and construction, water resources for domestic use and livestock, harvesting wild honey, collecting medicinal plants, and wild fruits. Nearly all natural forests offer similar functions (e.g. Odhiambo, 2005; Kiruki, 2000) but the degrees of dependence vary among climatic zones. Communities in 
less humid areas depend much more on non-wood forest products from natural vegetation than those in high potential areas where there are more diverse economic activities.

\subsection{Regulating natural resource use: Management issues}

\subsubsection{Empowering local communities}

Communities adjacent to Kirisia Forest are heavily dependent on the forest, but the current levels of exploitation are not sustainable. There is need to develop sustainable management systems which involve participation of locals and other stakeholders. The pastoralists in Kenya are usually associated with savannah and grassland ecosystems but in times of climate change and growing poverty, the Kirisia forest shows that dryland forests play a unique role in sustaining pastoralists' livelihoods. Being in a relatively dry area and surrounded by a pastoral community, water and dry season grazing emerged to be very important products to the community. However, there is need to enhance education system in the area for human resources development and community empowerment in joint forest management. Currently, levels of literacy are very low around Kirisia forest. High literacy levels would enhance access to information, negotiation skills and records keeping which are key to sustainable natural resource management and catalyze speedy improvement of livelihoods. Communities around the forest must be empowered in tree planting around settlements as they progressively shift from nomadic to sedentary life in order to reduce heavy reliance on natural forest timber as construction materials. They should also be empowered to venture into eco-friendly enterprises and to add value to their products.

\subsubsection{Conflict management and damage control}

People around the Kirisia Forest have been in conflicts with wild animals over mainly predation on livestock, damage to agricultural crops outside the forest and transmission of diseases to livestock. Rare cases of human deaths caused by hostile wild animals were also mentioned. Listed unfriendly animals include elephants, hyena, leopards, lions, poisonous snakes, ticks, tsetse flies and water-borne pests / parasites. The fact that livestock grazing in large numbers in Kenya's natural forests is the cause of much damage to natural vegetation particularly regeneration through browsing and trampling was also observed by Kiama and Butvnski (1999). Even in high potential areas where fodder is grown outside the forest, the production is in most case insufficient and the nearby forest is relied upon (Odhiambo, 2005). Communities that surround the forest made negatively impact on the ecosystem through dry season grazing, forest fires, tree felling for honey harvesting, human encroachment for settlement, intensive exploitation of posts. The threats to good forest health that were encountered in the forest included debarking, defoliation, damage by fire , physical injuries to trees, dead trees, dying trees, fallen trees due to animals or wind, diseases, suppression, destructive honey harvesting, game damage such as elephant browsing, elephant debarking, and boring insect. Professional management practices can potentially mitigate majority of the damages. Major destructive agents in Kirisia forest were elephants and buffalos and man through grazing, fodder, trampling, honey hunting and fire. Forest degradation through trampling was high due to high number of grazing animals in the forest, both domestic and wild. The disturbance on trees in Kirisia Forest mainly affected two commercial species Olea africana and Juniperus procera across all the study sites. Unless specific measures are found to conserve these species, their relative importance is 
significantly declining and the destruction of the forest upper canopy will soon destabilize the entire ecosystem. Disturbance resulting from fodder scarcity and pasture degradation will be avoided by developing adequate sources of fodder and management of pastures outside the forest, either on private or communal land coupled with de-stocking and keeping manageable sizes of livestock herds. Improved grazing systems and beekeeping technologies will assist to control forest fires to a great extent.

\subsubsection{Medicinal plants, water and ecotourism development}

As much as possible, it is important to minimise the harvesting of bark, roots and stems or develop low impact harvesting techniques to ensure targeted species are not depleted. Other conservation and protection measures are: species domestication and demarcation of core conservation areas. There is also need to carry out thorough taxonomic and toxicological studies on medicinal plants in the region. Nevertheless, it is quite clear that conserving plant diversity in Kirisia is synonymous to conserving medicine and promoting people's health now and in the future. Household economic study on herbal medicine to gauge its impact on people's welfare is equally needed, e.g. determine how much savings compared to using alternative modern medicine. Training and technological innovations for value addition and quality assurance of herbal medicine would also enhance conservation and improve income generation. Water sources must be protected using proven technologies. To enhance ecotourism initiatives, mechanisms for un-skewed sharing of benefits must be put in place within the joint forest management framework.

\subsubsection{Management and conservation options: Participatory and landscape models}

Poor or lack of pasture management strategies / plan in Group Ranches, water scarcity due to erratic rainfall and overstocking contribute to pasture degradation and scarcity of pasture and fodder outside the forest during dry seasons. Due to its forest microclimate, Kirisia forest ecosystem is the only recourse to pastoralists from nearby Group Ranches during such critical seasons of water and fodder crisis. Fodder supply is a very important and critical socioeconomic role of the forest for the Samburu pastoralist community. It is therefore fitting to develop sustainable fodder utilization plan which would promote diversification of species harvested based on the existing supply and guide the regeneration of affected resource species to ensure sustainability. The plan would explore different silvopastoralism technologies and recommend sustainable management of pastures within and outside the forestland. Pasture and fodder management is an attractive entry for joint management of Kirisia Forest between Group Ranches surrounding the forest and the State represented by Kenya Forest Service. Due to the critical function of the forest as a unique habitat to wildlife within the landscape, the Kenya Wildlife Service is an inevitable third stakeholder to include in this scheme of joint management of the Kirisia. Conservation of Kirisia forest is very critical to livelihood of beekeepers and other honey users around the forest. A refinery has now been constructed through the help of AWF and technical support from the International Centre for Insect Physiology and Ecology (ICIPE). It is run by a local beekeeping cooperative. Through this initiative, extracted honey is of certified quality, well packaged and sold to markets outside the production region. In addition, other products like beeswax and sting are produced. The refinery is promoting off-farm employment to some cooperative members. Based on honey harvesting results and associated damages, it is important to continue promoting beekeeping outside the forest and ecologically safer 
methods of honey collection. These initiatives would significantly contribute to the conservation of the forest and its resources therein and enhance the socioeconomic value of the forest for current and future generations. As stated by FAO (1993), banning the production and or marketing of charcoal has proved counterproductive: "bans do not reduce production but drive producers to underground, thereby precluding proper control of production procedures". The best option is to manage this charcoal sector in a sustainable, environmentally-friendly manner as follows (Girard, 2002):

- Encourage widespread use of well designed energy-efficient charcoal stoves,

- Promote tree planting outside the Kirisia Forest Reserve with quality energy species

- Introduce proper forest management practices and regulations based on the biological potential of affected species to regenerate,

- Encourage diversification of species used; promote fast-growing even if they produce less dense charcoal; market them on weight- rather than volume-bases

- $\quad$ Produce technologies to produce more charcoal using less wood

- Encourage local communities to use other sources of fuel e.g. bio-gas, solar energy.

- Encourage actors in charcoal production-marketing chain to be organised in registered groups once the Charcoal policy Paper in Kenya is put in place.

Sustainable production and use of charcoal can have a significant impact by helping to conserve resources, reducing massive migrants from rural or forested areas to urban or commercial centres and by improving people's incomes (Girard, 2002).

\section{Conclusion and recommendations}

Kirisia Forest is of great ecological, social and economic importance to the surrounding communities. Threats facing the Kirisia forest and its constituent resources are mainly anthropogenic and can be effectively addressed through joint effort between the State, local Communities and other stakeholders. There is need to urgently initiate, develop and implement a sustainable forest management plan embracing the participatory approach. At the same time, it is critical for the community to develop community-based natural resources management plans to optimise utilization and ensure sustainability of locally available resources in Group Ranches. This will minimise direct dependence on the forest and mitigate potential conflicts. Areas with highest focus in developing the joint management model should include: herbal medicine, beekeeping, wildlife conservation and ecotourism (nature-based enterprises), charcoal use and production outside the forest (i.e. in Group Ranches and consumption Centres), pasture management and animal husbandry. Providing alternative options to destructive consumptive uses of forest resources would minimize major threats to the ecosystem.

\section{Acknowledgements}

Authors acknowledge the financial support from African Wildlife Foundation (AWF), The Royal Government of Netherlands and USAID. We also appreciate the administrative support from the Forest Department (now KFS), Samburu District. Special thanks go to the field teams during data collections and to the AWF GIS Experts for their professional input during the planning of field visits and production of resource maps thereafter. We sincerely thank the Samburu Community in Mbaringon, Lkiloriti (Baawa), Ledero and Lodokejek for their support and cooperation. 


\section{Appendices}

\section{Appendix A: Checklist of animal life in the Kirisia Forest ecosystem, Samburu, Kenya,} 2005

Wild animals

Aardvark

Ants

Baboon

Bees

Buffalo

\section{Sign of presence}

Holes and physical presence

Physical presence on plants, anthills

Skull, physical presence, sound, foot marks

Physical presence, trace of honey harvesting on felled trees (Juniperus procera, Croton megalocarpus, Podocarpus sp, Olea capensis ssp hotchestetteri

Physical presence, carcasses (bone, skull, teeth), fresh dung, foot marks, drinking points, resting grounds, droppings, trails, grazing areas, hair on tree trunks,

Bush pig / Wild pig Feaces, foot marks

Bushbuck

Butterflies

Dik dik

Eland

Elephant

Gazelle

Hyena

Kelly frankolin

Leopard

Lintutal

Lion

Porcupine

Safari ants

Tree Squirrel

Warthog

Waterbuck

Zebra
Physical presence, Foot marks, salt points, sleeping place, freshly killed animal

Physical presence

Foot print

Physical presence, foot marks

Physical presence, bathing points, types of damages on trees e.g. Debarking, carcasses (bones, skull), resting places, trails, droppings, foot marks, play ground, salt points,

Physical presence, fresh urine, feaces, salt point

Foot marks

Physical presence

Foot marks, freshly killed prey by a leopard, skull

Physical presence

Foot mark

Quills (i.e. Spikes)

Physical presence

Physical presence

Foot marks, brushing point, ground scratches, droppings, sleeping place, skull,

Foot marks, resting place, trails

Sound, dung / droppings 
Appendix B: Key bird species recorded from Kirisia Forest (Oct-Nov 2005) and their preferred habitat types

\begin{tabular}{|c|c|c|}
\hline Common names & $\begin{array}{l}\text { Scientific names } \\
\text { (Samburu names) }\end{array}$ & Preferred habitat types \\
\hline $\begin{array}{l}\text { 1. (African) Paradise } \\
\text { Flycatcher }\end{array}$ & Terpsiphone viridis & Widespread, locally common. \\
\hline $\begin{array}{l}\text { 2. (Nominate) Baglafecht } \\
\text { Weaver (- allied to } \\
\text { Reichenow's weaver (P. } \\
\text { baglafecht reichenowi) }\end{array}$ & Ploceus sp & $\begin{array}{l}\text { Moorland bush, forest margins, } \\
\text { grass and scrub, highlands of } \\
\text { Kenya }\end{array}$ \\
\hline $\begin{array}{l}\text { 3. (White?) Yellow Throated } \\
\text { Nicator }\end{array}$ & Nicator vireo & \\
\hline 4. Abyssinian Crimsonwing & Cryptospiza salvadorii & $\begin{array}{l}\text { Undergrowth of forests and } \\
\text { bamboo }\end{array}$ \\
\hline $\begin{array}{l}\text { 5. Abyssinian Ground } \\
\text { Thrush }\end{array}$ & Turdus piaggiae & $\begin{array}{l}\text { Lush bush, margins of forests and } \\
\text { lush grass near water }\end{array}$ \\
\hline 6. African Dusky Flycatcher & Alseonax adustus & Wooded and Forest areas \\
\hline $\begin{array}{l}\text { 7. African Little Sparrow } \\
\text { Hawk }\end{array}$ & $\begin{array}{l}\text { Accipiter minullus } \\
\text { (Lonya Kweny) }\end{array}$ & $\begin{array}{l}\text { Woodland and forest hawk; } \\
\text { uncommon and local } \\
\text { (Endemic to woodlands and } \\
\text { forests). }\end{array}$ \\
\hline 8. Augur Buzzard & $\begin{array}{l}\text { Buteo rufofuscus } \\
\text { (Lmagiro) }\end{array}$ & Forest glades \\
\hline 9. Barbet & (Lodidioi) & $* * * *$ \\
\hline $\begin{array}{l}\text { 10. Black Fronted Bush } \\
\text { Shrike }\end{array}$ & Malaconotus migrifrons & High level forests \\
\hline 11. Black Kite & Milvus migrans & $\begin{array}{l}\text { Resident and local migrant; } \\
\text { savannah and open country }\end{array}$ \\
\hline 12. Black-Headed Oriole & $\begin{array}{l}\text { Oriolus larvatus } \\
\text { (Lkirapach / Lpolpol) }\end{array}$ & $\begin{array}{l}\text { Partial migrant of open woodland, } \\
\text { scrub, highland forests, coastal } \\
\text { bush }\end{array}$ \\
\hline 13. Blue capped Cordon-Bleu & $\begin{array}{l}\text { Uraeginthus } \\
\text { cyanocephalus } \\
\text { (Ntaidi-idi) }\end{array}$ & Dry bush, less common. \\
\hline $\begin{array}{ll}\text { 14. } & \text { Brown-Headed } \\
\text { (crowned) Tchagra }\end{array}$ & $\begin{array}{l}\text { Tchagra australis } \\
\text { (Lomerei) }\end{array}$ & Scrub, woodland, undergrowth \\
\hline
\end{tabular}


Challenges of Linking Socio-Economic Significance and Conservation Value

\begin{tabular}{|c|c|c|}
\hline Common names & $\begin{array}{l}\text { Scientific names } \\
\text { (Samburu names) }\end{array}$ & Preferred habitat types \\
\hline $\begin{array}{l}\text { 15. Cinnamon Bracken } \\
\text { Warbler }\end{array}$ & $\begin{array}{l}\text { Bradypterus } \\
\text { cinnamomeus }\end{array}$ & $\begin{array}{l}\text { In or near mountain forests, } \\
\text { at } 3800 \mathrm{~m} \text { a.s.l and above, } \\
\text { In thick tangled undergrowth, } \\
\text { bush, bracken and bamboo. }\end{array}$ \\
\hline 16. Collarded Sunbird & $\begin{array}{l}\text { Anthreptes collaris } \\
(\mathrm{Njim})\end{array}$ & $\begin{array}{l}\text { Forests, woodland, scrub and } \\
\text { bushes }\end{array}$ \\
\hline $\begin{array}{l}\text { 17. Common (Namaqua) } \\
\text { Dove }\end{array}$ & $\begin{array}{l}\text { Oena capensis } \\
\text { (Nkutukurnk) }\end{array}$ & $\begin{array}{l}\text { Arid and Semi-desert bush country, } \\
\text { Acacia stands especially in sandy } \\
\text { areas and } \\
\text { open dry woodlands }\end{array}$ \\
\hline 18. Common Bulbul & (Nkirokie) & $* * * *$ \\
\hline 19. Fan-Tail Raven & Corvus rhipidurus & $\begin{array}{l}\text { Rocky hill country and near camps } \\
\text { and } \\
\text { human habitations as a scavenger }\end{array}$ \\
\hline 20. Green Backet Twinspot & Mandingoa nitidula & $\begin{array}{l}\text { Dense undergrowth of forests, } \\
\text { thickets and heavy vegetation } \\
\text { along streams. }\end{array}$ \\
\hline 21. Grey Apalis & Apalis cinerea & Forest tree top and undergrowth \\
\hline $\begin{array}{l}\text { 22. Grey Backed } \\
\text { Camaroptera }\end{array}$ & $\begin{array}{l}\text { Camaroptera } \\
\text { brevicaudata } \\
\text { (Nakudel) }\end{array}$ & $\begin{array}{l}\text { In both highland and lowland } \\
\text { forests, } \\
\text { wooded and scrub vegetation }\end{array}$ \\
\hline 23. Grey Cockoo Shrike & Coracina caesia & Evergreen mountain forests \\
\hline 24. Grey Parrott & Psittacus erithacus & In flocks; in tops of forest trees \\
\hline 25. Hartlaub's Turaco & $\begin{array}{l}\text { Tauraco hartlaubi } \\
\text { (Ngewa) }\end{array}$ & $\begin{array}{l}\text { Highland forests; common in } \\
\text { forests } \\
\text { around Nairobi }\end{array}$ \\
\hline 26. Lemon Dove & Aplopelia larvata & $\begin{array}{l}\text { Shy, sensitive bird, largely on the } \\
\text { ground. }\end{array}$ \\
\hline 27. Lesser Honey Guide & $\begin{array}{l}\text { Indicator minor } \\
\text { (Nchochoroi) }\end{array}$ & $\begin{array}{l}\text { A variety of habitats from forests to } \\
\text { woodlands. }\end{array}$ \\
\hline $\begin{array}{l}\text { 28. Long-Tailed Fiscal } \\
\text { (Shrike) }\end{array}$ & $\begin{array}{l}\text { Lanius cabanisi } \\
\text { (Lkerekitag) }\end{array}$ & $\begin{array}{l}\text { In coastal area of Kenya and on } \\
\text { the Athi plains }\end{array}$ \\
\hline $\begin{array}{l}\text { 29. Northen Double } \\
\text { Collarded Sunbird }\end{array}$ & Nectarinia preussi & Mountain forests in Kenya \\
\hline
\end{tabular}




\section{Appendix B (Continued)}

\begin{tabular}{|c|c|c|}
\hline Common names & $\begin{array}{l}\text { Scientific names } \\
\text { (Samburu names) }\end{array}$ & Preferred habitat types \\
\hline 1. Nubian Wood Pecker & $\begin{array}{l}\text { Campethera nubica } \\
\text { (Ltilo) }\end{array}$ & $\begin{array}{l}\text { Open bush, Acacia woodland, } \\
\text { often common }\end{array}$ \\
\hline 2. Olive Thrush & Turdus olivaceus & $* * * *$ \\
\hline 3. Robin Chat & Cassypha caffra & $\begin{array}{l}\text { Widespread, mostly above } 1530 \mathrm{~m} \\
\text { a.s.l., } \\
\text { forests, wooded and scrub areas }\end{array}$ \\
\hline $\begin{array}{l}\text { 4. Rossy Patched Bush } \\
\text { Shrike }\end{array}$ & (Losir-Monyaa) & Tree top foliage \\
\hline 5. Scaly Francolin & $\begin{array}{l}\text { Francoline squamatus } \\
\text { (Lkurle lentim) }\end{array}$ & $\begin{array}{l}\text { Forests, thick bush near forests, } \\
\text { Kenya highlands; A local bird, } \\
\text { absent from many apparently } \\
\text { suitable } \\
\text { localities }\end{array}$ \\
\hline $\begin{array}{l}\text { 6. Slivery-Cheeked } \\
\text { Hornbill }\end{array}$ & Bycanistes brevis & $\begin{array}{l}\text { Mainly a forest species; } \\
\text { many in Kenya coastal forests }\end{array}$ \\
\hline 7. Sooty Ant Eater & & $* * * *$ \\
\hline 8. Speckled Mousebird & $\begin{array}{l}\text { Colius striatus } \\
\text { (Lmodooni) }\end{array}$ & $\begin{array}{l}\text { Forested and wooded areas, } \\
\text { dense scrub; destructive to growing } \\
\text { vegetables and fruit trees }\end{array}$ \\
\hline 9. Square-Tailed Drongo & $\begin{array}{l}\text { Dicrurus ludwigii } \\
\text { (Lkurdudu) }\end{array}$ & $\begin{array}{l}\text { Forests, dense woodland, } \\
\text { most frequent in western Kenya }\end{array}$ \\
\hline \multicolumn{3}{|l|}{ 10. Squirrel } \\
\hline 11. Streaky Seed-eater & Serinus striolatus & \\
\hline 12. Superb Starlling & $\begin{array}{l}\text { Spreo superbus } \\
\text { (Surpelei) }\end{array}$ & $\begin{array}{l}\text { Widespread resident and partial } \\
\text { migrant. Thorn bush, Acacia } \\
\text { vegetation and near human } \\
\text { settlements. }\end{array}$ \\
\hline 13. Tropical Boubou & $\begin{array}{l}\text { Laniarius ferrugineus } \\
\text { (Lmongo Lwaas) }\end{array}$ & $\begin{array}{l}\text { Thick cover in forests, woodland, } \\
\text { riverine thickets, bush }\end{array}$ \\
\hline $\begin{array}{l}\text { 14. White (Stared) } \\
\text { Throated Robbin }\end{array}$ & Irania gritturalis & $\begin{array}{l}\text { Dense scrub, along dry riverbeds, } \\
\text { Winter visitor from Asia }\end{array}$ \\
\hline
\end{tabular}


Challenges of Linking Socio-Economic Significance and Conservation Value

\begin{tabular}{|l|l|l|}
\hline $\begin{array}{l}\text { 15. } \\
\text { White Eyed Slaty }\end{array}$ & Dioptrornis fischeri & Highland forest, forest margins. \\
\hline 16. Yellow White Eye $* * * *$ & & $* * * *$ \\
\hline $\begin{array}{l}\text { 17. Yellow-Whiskered } \\
\text { Greenbul }\end{array}$ & Andropadus latirostris & $\begin{array}{l}\text { Eastern Kenya Highlands and } \\
\text { western Kenya }\end{array}$ \\
\hline
\end{tabular}

Source: Field Survey (Oct - November 2005), identification by Robert Rosano Lentareia (Field guide) and edited based on Williams and Arlott (1985) - A Field Guide to the Birds of East Africa.

\section{References}

Eckersley, R. (1992). Environmentalism and political theory: Towards an ecocentric approach. London University College, London Press.

Falconer, J. and Arnold, J.E.M. (1989). Household food security and forestry: an analysis of socioeconomic issues. Community Forestry Note 1, FAO, Rome.

FAO (1993). A decade of wood energy activities within the Nairobi Programme of Action. FAO Forestry Paper No. 63, Rome.

Girard, P. (2002). Charcoal production and use in Africa: what future? Unasylva, 53 (211): 30-34.

Gow, D.D. (1992). Forestry for sustainable development: the social dimension. Unasylva 43 (169). www.fao/org/forestry/unasylva.stm

Hitimana , J., Kiyiapi, J., Kisioh, H., Warinwa, F., Lenaiyasa, P., Mayienda, R., and Daudi Sumba, D. (2009). Participatory ecological assessment of Kirisia forest reserve, samburu, Kenya. AWF Technical Paper Series, African Wildlife Foundation, Nairobi.

Hitimana, J., Kiyiapi, J.L., Njunge, J.T. (2004). Forest structure characteristics in disturbed and undisturbed sites of Mt. Elgon Moist Lower Montane Forest, western Kenya. Forest Ecology \& Management 194: 269-291.

Ikua, W. \& Sommerlatte, M. (2007). A Tourism Strategy For Samburu District (Final Report). Commissioned By The African Wildlife Foundation With Support From Tourism Trust Fund.

Jaetzold, R. \& Schmidt, H. (1983). Farm management Handbook vol II- Natural conditions and Farm management information, Part B Central Kenya (Rift Valley and Central Provinces). Ministry of Agriculture, Kenya, in cooperation with the German Agricultural Team (GAT) of the GTZ, Nairobi

Kiama, D. and Butynski, T.M. (1999). Distribution and abundance of trees in the Aberdares ecosystem, Kenya. In: Butynski, T.M.: Aberdares National Park and Aberdares Forest Reserves Wildlife fence placement study and recommendations. A report for the Kenya Wildlife Service and the Kenya Forestry Department. Zoo Atlanta's Africa Conservation Program. Appendix II.

Kiruki, H. M. (2000). A review of the state of community forestry in Kenya. A report presented to Forest Action Network, September 2000.

MKK (2005). Kirisia Forest Beekeepers : A Baseline Study. Draft Report. Mkk Ltd.

Njunge, T.J., (1996). Species composition and regeneration of South Nandi Forest. PhD Thesis. University of Wales, UK. 
Odhiambo, J.M. (2005). Forest utilization by adjacent communities: a case study of kiandogoro Forest in the Aberdares Region, Kenya. MPhil Thesis, Moi University, Eldoret, Kenya.

Republic of Kenya (2005). The Forests Act 2005. Kenya Gazette Supplement No. 88 (Acts No. 7); The Government Printers, Nairobi.

Watai, M.K. and Gachathi, F.N. (2003). Conservation for Sustainable Utilization of Biodiversity through enhanced access and Benefit Sharing with Forest adjacent Communities in Kirisia Forest Samburu District. Report for African Wildlife Foundation, Samburu Heartland

Whittaker, R.H.(1975). Communities and Ecosystems. 2nd Ed., McMil. Pub., New York. 


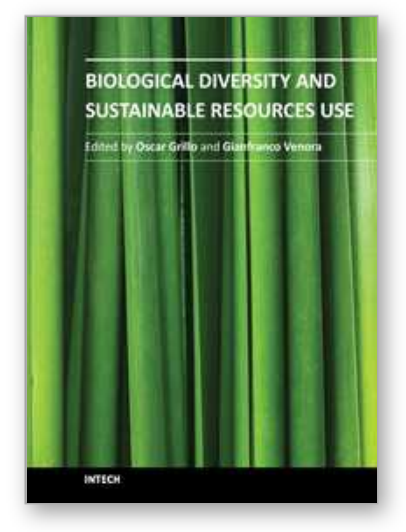

\author{
Biological Diversity and Sustainable Resources Use \\ Edited by PhD. Oscar Grillo
}

ISBN 978-953-307-706-2

Hard cover, 158 pages

Publisher InTech

Published online 14, November, 2011

Published in print edition November, 2011

Biological Diversity and Sustainable Resources Use is a very interesting volume, including attractive overviews and original case studies mainly focused on socio-economical effects of the right management of the ecosystems biodiversity, as well as on the useful integration between human activities and environmental responses. Ecological, medical and historical aspects of the sustainable development are also discussed in this book which consists of articles written by international experts, offering the reader a clear and extensive view of the present condition in which our planet is.

\title{
How to reference
}

In order to correctly reference this scholarly work, feel free to copy and paste the following:

Joseph Hitimana, James Legilisho Ole Kiyiapi, Pauline Wambui Kibugi, Hamphrey Kisioh, Rose Mayienda, Fiesta Warinwa, Philip Lenaiyasa and Daudi Sumba (2011). Challenges of Linking Socio-Economic Significance and Conservation Value of Forests in Drylands of Kenya: Case Study of Kirisia Forest-Samburu Pastoralists Coexistence, Biological Diversity and Sustainable Resources Use, PhD. Oscar Grillo (Ed.), ISBN: 978-953-307-706-2, InTech, Available from: http://www.intechopen.com/books/biological-diversity-andsustainable-resources-use/challenges-of-linking-socio-economic-significance-and-conservation-value-offorests-in-drylands-of-k

\section{INTECH}

open science | open minds

\author{
InTech Europe \\ University Campus STeP Ri \\ Slavka Krautzeka 83/A \\ 51000 Rijeka, Croatia \\ Phone: +385 (51) 770447 \\ Fax: +385 (51) 686166 \\ www.intechopen.com
}

\author{
InTech China \\ Unit 405, Office Block, Hotel Equatorial Shanghai \\ No.65, Yan An Road (West), Shanghai, 200040, China \\ 中国上海市延安西路65号上海国际贵都大饭店办公楼 405 单元 \\ Phone: +86-21-62489820 \\ Fax: $+86-21-62489821$
}


(C) 2011 The Author(s). Licensee IntechOpen. This is an open access article distributed under the terms of the Creative Commons Attribution 3.0 License, which permits unrestricted use, distribution, and reproduction in any medium, provided the original work is properly cited. 